\title{
Titanium dioxide in our everyday life; is it safe?
}

\author{
Matej Skocaj ${ }^{1}$, Metka Filipic², Jana Petkovic², Sasa Novak \\ 1 Jožef Stefan Institute, Department for Nanostructured Materials, Ljubljana, Slovenia \\ ${ }^{2}$ National Institute of Biology, Department for Genetic Toxicology and Cancer Biology, Ljubljana, Slovenia
}

Received 7 October 2011

Accepted 27 October 2011

Correspondence to: Saša Novak, Jožef Stefan Institute, Department for Nanostructured Materials, Jamova 39, SI-1000 Ljubljana, Slovenia. Phone: +386 14773 271; Fax: +386 14773 221; E-mail: sasa.novak@ijs.si

Disclosure: No potential conflicts were disclosed.

Background. Titanium dioxide $\left(\mathrm{TiO}_{2}\right)$ is considered as an inert and safe material and has been used in many applications for decades. However, with the development of nanotechnologies $\mathrm{TiO}_{2}$ nanoparticles, with numerous novel and useful properties, are increasingly manufactured and used. Therefore increased human and environmental exposure can be expected, which has put $\mathrm{TiO}_{2}$ nanoparticles under toxicological scrutiny. Mechanistic toxicological studies show that $\mathrm{TiO}_{2}$ nanoparticles predominantly cause adverse effects via induction of oxidative stress resulting in cell damage, genotoxicity, inflammation, immune response etc. The extent and type of damage strongly depends on physical and chemical characteristics of $\mathrm{TiO}_{2}$ nanoparticles, which govern their bioavailability and reactivity. Based on the experimental evidence from animal inhalation studies $\mathrm{TiO}_{2}$ nanoparticles are classified as "possible carcinogenic to humans" by the International Agency for Research on Cancer and as occupational carcinogen by the National Institute for Occupational Safety and Health. The studies on dermal exposure to $\mathrm{TiO}_{2}$ nanoparticles, which is in humans substantial through the use of sunscreens, generally indicate negligible transdermal penetration; however data are needed on long-term exposure and potential adverse effects of photo-oxidation products. Although $\mathrm{TiO}_{2}$ is permitted as an additive (E171) in food and pharmaceutical products we do not have reliable data on its absorption, distribution, excretion and toxicity on oral exposure. $\mathrm{TiO}_{2}$ may also enter environment, and while it exerts low acute toxicity to aquatic organisms, upon long-term exposure it induces a range of sub-lethal effects.

Conclusions. Until relevant toxicological and human exposure data that would enable reliable risk assessment are obtained, $\mathrm{TiO}_{2}$ nanoparticles should be used with great care.

Key words: titanium dioxide; nanoparticles; toxicity; applications; safety

\section{Introduction}

Titanium dioxide (titania, $\mathrm{TiO}_{2}$ ) is chemically inert, semiconducting material that also exhibits photocatalytic activity in the presence of light with an energy equal to or higher than its band-gap energy. These characteristics offer a wide range of applications. For these reasons, and because of the relatively low price of the raw material and its processing, titania has gained widespread attention over recent decades.

$\mathrm{TiO}_{2}$ has been classified in humans and animals as biologically inert ${ }^{1,2}$, and is widely considered to be a "natural" material, which at least partially contributes to its relatively positive acceptance by the public. In fact, most $\mathrm{TiO}_{2}$ has been synthesized from the mineral illmenite, $\mathrm{FeTiO}_{3}$, using the "sulphate" or "chloride" process for nearly 100 years.
The annual worldwide production of titania powder in 2005 has been estimated to be around 5 million tons ${ }^{3}$, provoking the question as to its abundance in the environment. The proportion of nano-sized titania is estimated to have been approximately $2.5 \%$ in 2009, increasing to $10 \%$ by $2015^{4}$, with an exponential increase over the past decade.

During recent decades, $\mathrm{TiO}_{2}$ powders have begun to appear in many applications, mainly due to their ability to confer whiteness and opacity on various products, such as paints, papers and cosmetics. Its high technological attractiveness originates from its light-scattering properties and very high refractive index, which mean that relatively low levels of the pigment are required to achieve a white, opaque coating. The range of light that is scattered depends on the particle size. Numerous technological improvements, based on nano-sized 

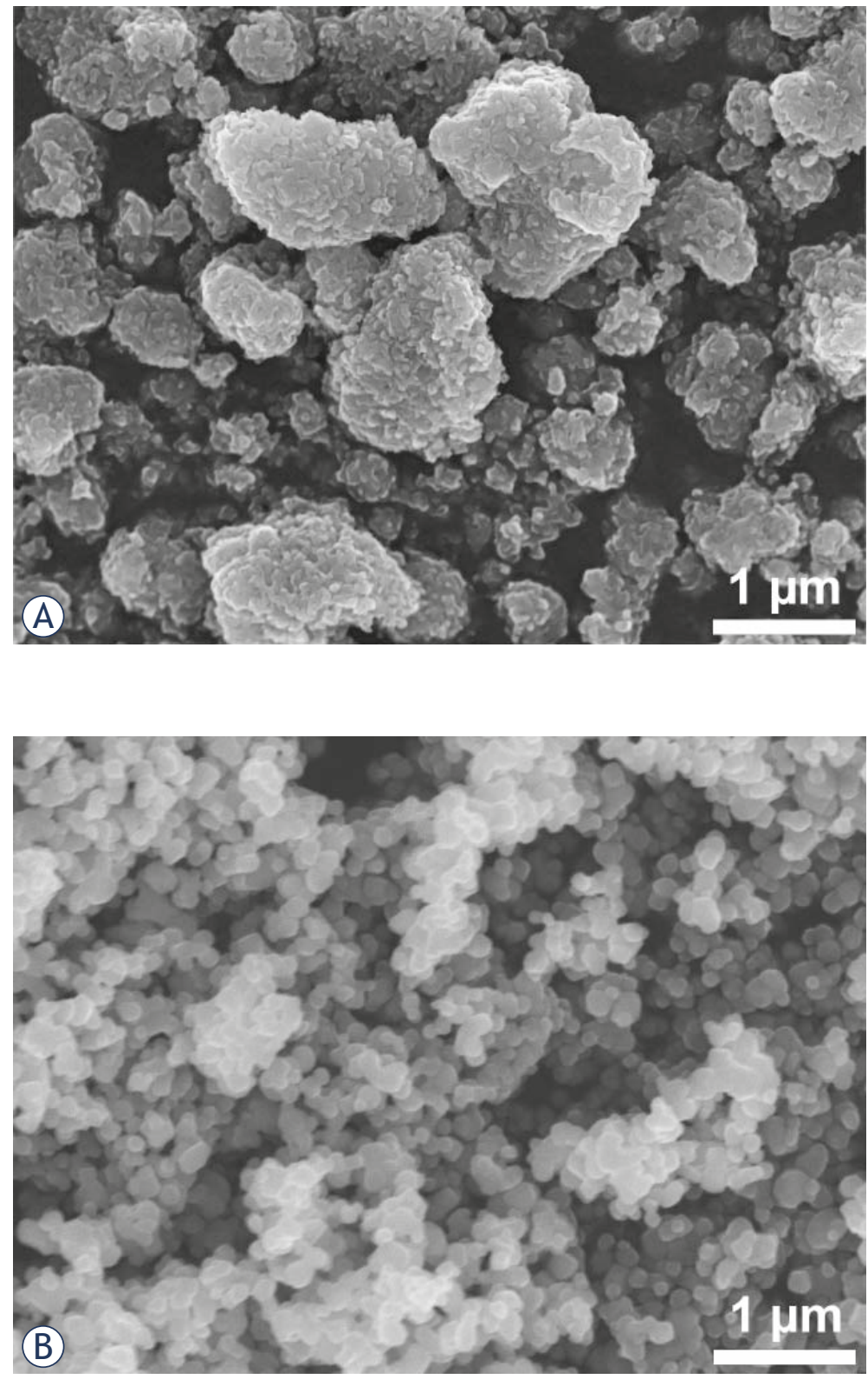

$\mathrm{TiO}_{2}$, have been introduced that enable its use for antifogging and self-cleaning coatings on glass, for building facades, in confectionary, in the plastics industry, and so on. Furthermore, $\mathrm{TiO}_{2}$ is accepted as a food and pharmaceutical additive. ${ }^{5}$ In the United States it is included in the Food and Drug Administration (FDA) Inactive Ingredients Guide for dental paste, oral capsules, suspensions, tablets, dermal preparations and in non-parenteral medicines.

The increasing production of nano-sized $\mathrm{TiO}_{2}$ powder has led to growing concerns about the consequences of exposure of humans and the environ-

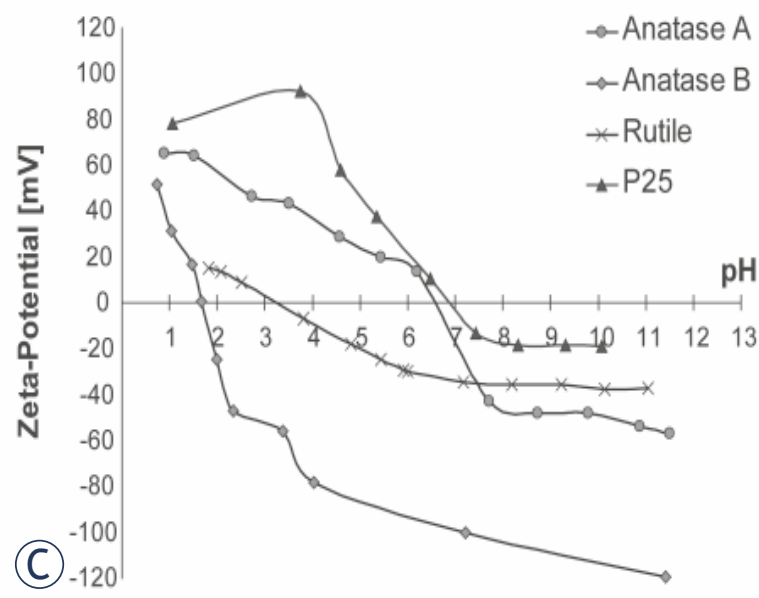

FIGURE 1. Field emission electron micrographs of different $\mathrm{TiO}_{2}$ powders: A) Anatase A (Sigma 637254), B) Anatase B (Sigma T8141); C) Zeta-potential of these two powders, Rutile (Sigma 637262) and P25 (Degussa).

ment. ${ }^{6}$ In the present paper we review and discuss the latest findings on potential hazard of exposure to nano-sized $\mathrm{TiO}_{2}$ for humans and environment, in regard to the particle size and the crystal structure of $\mathrm{TiO}_{2}$, the route of exposure as well as the effect of ultraviolet (UV) irradiation-induced photocatalysis.

\section{Chemical and physical properties of $\mathrm{fiO}_{2}$ nanoparticles}

Nanoparticles (NPs) are generally defined as particles having at least one dimension smaller than 100 $\mathrm{nm}$. Accordingly, particles with different morphologies, from equi-axial shapes, whiskers, and nanotubes to nanorods, need to be considered. Although micron-sized and nano-sized $\mathrm{TiO}_{2}$ powders are, in general, chemically identical, due to their significantly higher specific surface area, nano-powders may exhibit physical and chemical properties that differ from those of the coarser grades, and so should not be treated in the same way. In a recent paper $^{7}$ the size-dependent properties of a variety of inorganic NPs were reviewed and it was suggested that they are likely to be of concern due to the appearance of unique properties when they have diameters of $\leq 30 \mathrm{~nm}$. In this size range, many particles undergo dramatic changes in behaviour that enhance their interfacial reactivity. While less than $20 \%$ of the constituent atoms are at the surface of $30 \mathrm{~nm}$ NPs, approximately $35-40 \%$ of the atoms are localized at the surface of a $10 \mathrm{~nm}$ particle. 
In practice, it is difficult to draw a clear borderline between nano- and submicron-sized particles. Submicron-sized powders always contain a certain proportion of nano-sized particles and, conversely, NPs tend to associate to form relatively strongly bonded aggregates (Figure 1A) or soft agglomerates (Figure 1B). The latter can usually be disintegrated easily in a liquid; however, their dispersion depends strongly on the zeta-potential. As illustrated in Figure 1C, the zeta-potential of $\mathrm{TiO}_{2}$ powders may differ significantly over a wide range of $\mathrm{pH}$ values. The reported isoelectric points for $\mathrm{TiO}_{2}$ powders range from $\mathrm{pH} 3.5$ to $8^{8}$ which may greatly affect the bioavailability in the region of physiological $\mathrm{pH}$ values. The effective size of particles and their zeta-potential have been neglected almost completely in most of the studies of the interaction of $\mathrm{TiO}_{2}$ NPs with biological systems.

Crystalline $\mathrm{TiO}_{2}$ occurs naturally in three polymorphs - anatase, rutile and brookite - among which rutile is the most stable. A powder with an average particle size of $230 \mathrm{~nm}$ scatters visible light, while its counterpart, with an average size of $60 \mathrm{~nm}$, scatters UV light and reflects visible light. Under $\mathrm{UV}, \mathrm{TiO}_{2}$ exhibits photocatalytic activity, which is a consequence of the electronic structure of the titania, and is, to a large extent, more characteristic of anatase than of rutile and brookite. In the presence of light with energy equal to or higher than the $\mathrm{TiO}_{2}$ band-gap energy, an electron is promoted from the valence band to the conduction band, leaving behind a positive hole. The extrapolated optical absorption gaps of anatase and rutile are 3.2 and $3.0 \mathrm{eV}$ at room temperature, which correspond to wavelengths of around 413 $\mathrm{nm}$ and $387 \mathrm{~nm}$. Consequently, the photo-activation of nano- $\mathrm{TiO}_{2}$ can be achieved by irradiation with UV-A, B and C, visible, fluorescent light, and $\mathrm{X}$-ray radiation. The photocatalytic activity results in formation of highly reactive radicals, that are capable of reacting with most of the surrounding organic substances. ${ }^{9-12}$

\section{Mechanisms of $\mathrm{TiO}_{2}$ NPs toxicity}

As already discussed, the physicochemical properties of particles depend on their size, so that, at the nanometre level, the material is chemically more reactive. This can be exploited as a desirable property, e.g., as a catalyst. However, at the same time, the material may possess biological activities that can be either desirable (e.g., carrier capacity for therapeutics, penetration of cellular barriers for drug delivery) or undesirable (e.g., toxicity, induction of oxidative stress or cellular dysfunction), or a mix of the two.

\section{Cellular uptake of $\mathrm{TiO}_{2}$ NPs}

From a toxicological point of view the important characteristics of NPs are their size, surface area, surface chemistry and charge, crystallinity, shape, solubility and agglomeration/aggregation state. Surface groups may render NPs hydrophilic or hydrophobic, lipophilic or lipophobic, catalytically active or passive. Cellular uptake, subcellular localization, and ability to cause toxic effects depend on these properties of NPs. ${ }^{13}$ The two main pathways of NP uptake in the cell are active uptake by endocytosis, and passive uptake by free diffusion. Phagocytosis is an actin-dependent, endocytic mechanism, typical of "professional" phagocytes like macrophages. Geiser et al. ${ }^{14}$ reported that, in rats exposed to $\mathrm{TiO}_{2}$ powders by inhalation, alveolar macrophages effectively cleared micron-sized (3-6 $\mu \mathrm{m})$ but not nano-sized (20 nm) $\mathrm{TiO}_{2}$ particles. This is important, since phagocytes generally remove particulate matter $>500 \mathrm{~nm}{ }^{15}$ and, as they are unable to phagocytose smaller particles, the latter are retained in the tissue, leading to a sustained burden on other tissues and cells. It was demonstrated that the uptake of $50 \mathrm{~nm}$ nano- $\mathrm{TiO}_{2}$, by endocytosis with alveolar A549 epithelial cells, was limited to aggregated particles. ${ }^{16}$ After inhalation exposure of rats to $\mathrm{TiO}_{2} \mathrm{NPs}$, free particles were found within the cytoplasm of epithelial and endothelial cells and fibroblasts. ${ }^{17}$ Rothen-Rutishauser et al. ${ }^{18}$, used an in vitro airway wall model, and found membrane-bound aggregates $(>200 \mathrm{~nm})$ of $\mathrm{TiO}_{2}$ as well as smaller unbound aggregates within the cell cytoplasm. In an in vitro study Kocbek et al. ${ }^{19}$ demonstrated the endocytotic uptake of $25 \mathrm{~nm}$ sized anatase $\mathrm{TiO}_{2}$ by human keratinocytes. They observed highly aggregated NPs within early and late endosomes and in amphisomes, confirming endocytotic uptake. Experiments with red blood cells, which lack phagocytic receptors ${ }^{18}$, revealed that $\mathrm{TiO}_{2} \mathrm{NP}$ aggregates smaller than $200 \mathrm{~nm}$ are able to enter red blood cells, while larger particles were only found attached to the cell's surface. Xia et al. ${ }^{20}$ showed that fluorescence-labelled $\mathrm{TiO}_{2}$ NPs (11 nm) were taken up and localized in late endosomal and caveolar compartments in phagocytic RAW 246.7 and lung endothelial BEAS-2B cells. 


\section{Oxidative stress induced by $\mathrm{TiO}_{2} \mathrm{NPs}$}

Oxidative stress is thought to be a key mechanism responsible for adverse biological effects exerted by NPs. ${ }^{21,22}$ The role of oxidative stress in $\mathrm{TiO}_{2}-$ induced adverse effects has been confirmed by evidence that it induces an increase in reactive oxygen species (ROS) production and oxidative products (i.e., lipid peroxidation), as well as the depletion of cellular antioxidants. ${ }^{23-29}$

$\mathrm{TiO}_{2}$ mediates oxidative stress under UV irradiation as well as without it. Uchino et al. ${ }^{30}$ showed that, under UV irradiation, the $\mathrm{TiO}_{2} \mathrm{NPs}$ of different crystalline structures and sizes produces different amounts of hydroxyl radicals, and that cytotoxicity against Chinese hamster ovary cells correlates with the production of radicals. Dodd and Jha ${ }^{31}$ confirmed that hydroxyl radicals are the primary damaging species produced by UV irradiated nano-sized $\mathrm{TiO}_{2}$, and react to give carboxyl radicals. A number of studies have shown photoactivated anatase $\mathrm{TiO}_{2}$ to induce higher cytotoxicity and genotoxicity than similarly activated rutile $\mathrm{TiO}_{2}$. These differences could arise from the fact that anatase particles possess a wider absorption gap and a smaller electron effective mass, resulting in the higher mobility of the charge carriers and the greater generation of ROS. On the other hand, there is evidence that $\mathrm{TiO}_{2}$ also induces $\mathrm{ROS}$ formation and the associated adverse effects in the absence of photo-activation. For instance, Gurr et al. ${ }^{24}$ found that anatase $\mathrm{TiO}_{2}$ NPs and mixtures of anatase and rutile $\mathrm{TiO}_{2} \mathrm{NPs}$ induced oxidative damage in human bronchial epithelial (BEAS-2B) cells, and Petković et al. ${ }^{32}$ reported that in human hepatoma cells (HepG2), non-irradiated anatase nano- $\mathrm{TiO}_{2}$ induced significantly higher levels of intracellular ROS than the corresponding rutile- $\mathrm{TiO}_{2}$, and only anatase nano- $\mathrm{TiO}_{2}$ caused oxidative DNA damage. Recently, Petković et al..$^{33}$ compared cytotoxicity and genotoxicity of non-irradiated and UV preirradiated anatase $\mathrm{TiO}_{2}$ of two sizes $(<25 \mathrm{~nm}$ and $>100 \mathrm{~nm}$ ). They showed that non-irradiated $\mathrm{TiO}_{2}$ particles did not affect survival of the cells; they caused slight increase in number of DNA strand breaks, while only $\mathrm{TiO}_{2} \mathrm{NPs}$ caused increase in oxidative DNA damage. After pre-irradiation with UV both sizes of anatase $\mathrm{TiO}_{2}$ particles reduced cell viability, induced DNA strand breaks and oxidative DNA damage. This is an important finding that, for the first time, showed that photo-activated $\mathrm{TiO}_{2}$ particles retained higher cytotoxic and genotoxic potential also when UV irradiation was discontinued and that it was not particle size dependent.
ROS are also important signalling modulators, therefore exposure of cells to NPs may, via elevated ROS formation, affect cellular signalling cascades that control processes such as cell proliferation, inflammation and cell death. ${ }^{34}$ The role of oxidative stress in $\mathrm{TiO}_{2}$-induced inflammation has recently been confirmed by Kang et al. ${ }^{35} \mathrm{In}$ the mouse peritoneal macrophage cell line RAW 246.7 exposed to nano- $\mathrm{TiO}_{2}$, $\mathrm{ROS}$ production was associated with the activation of pro-inflammatory cascade, as indicated by extracellular signalregulated kinases ERK1/2 phosphorylation, tumour necrosis factor TNF $\alpha$ production and macrophage inflammatory protein MIP-2 secretion.

Taken together, these studies indicate that the high level of oxidative stress that is related to an exposure to a high concentration of $\mathrm{TiO}_{2}$ NPs leads to cell damage-associated responses, whereas at moderate levels of oxidative stress, inflammatory responses may be stimulated by the activation of ROS-sensitive signalling pathways.

\section{Genotoxicity of $\mathrm{TiO}_{2}$ NPs}

Several studies show that nano- $\mathrm{TiO}_{2}$ induces genotoxic effects, including DNA damage, and micronuclei formation that is indicative of chromosomal aberrations in different cell lines ${ }^{32,35-38}$ The studies also showed that genotoxic effects elicited by $\mathrm{TiO}_{2} \mathrm{NPs}$ strongly depended upon their size and form. For instance, Gurr et al. ${ }^{24}$ showed that anatase $\mathrm{TiO}_{2} \mathrm{NPs}$ up to $20 \mathrm{~nm}$ in size induced an increase in micronuclei formation, while $200 \mathrm{~nm}$ anatase or $200 \mathrm{~nm}$ rutile $\mathrm{TiO}_{2}$ did not. Zhu et al..$^{39}$ demonstrated clear differences in the cytotoxicity and the extent of DNA strand scission, together with the formation of 8-hydroxy-2-deoxyguanosine (8-OHdG) adducts in isolated DNA, after a treatment with different types of $\mathrm{TiO}_{2} \mathrm{NPs}$ in the order 10-20 nm anatase $>50-60 \mathrm{~nm}$ anatase $>50$ $60 \mathrm{~nm}$ rutile. At the molecular level it has been shown that the exposure of peripheral human lymphocytes to $\mathrm{TiO}_{2}$ NPs caused the activation of DNA damage check points and the accumulation of tumour suppressor protein p53, the main regulator of the cellular response to DNA damage. ${ }^{40}$ Exposure of human hepatoma HepG2 cells under similar conditions led to the elevated expression of tumor suppressor p53 mRNA and its downstream regulated DNA damage response genes (cyclin-dependent kinase inhibitor p21, growth arrest and DNA damage-inducible gene GADD45a and the E3 ubiquitin ligase MDM2). ${ }^{32}$ 
On the other hand, $\mathrm{TiO}_{2}$ NPs were devoid of mutagenic activity in microbial mutation assays (with Salmonella typhimurium) and in chromosomal aberration the in Chinese hamster ovary cells. ${ }^{41}$ Similarly, Theogaraj et al. ${ }^{42}$ reported that nano-sized $\mathrm{TiO}_{2}$ (eight different anatase and rutile forms) at concentrations up to $5 \mathrm{mg} / \mathrm{ml}$ did not induce any increase in the chromosomal aberration frequency in Chinese hamster ovary cells, in either the absence or the presence of UV light. However, in this study only a short-term, 3-hour, and no continuous (i.e., 20 hours) exposure, was performed.

In an early study Driscoll et al..$^{43}$ reported that in rats intratracheal instillation of $\mathrm{TiO}_{2}$ NPs (100 $\mathrm{mg} / \mathrm{kg} \mathrm{BW}$ ) induced increased HPRT mutation frequency in alveolar cells. They also showed that mutagenicity in alveolar cells was associated with inflammation. Trouiller et al. ${ }^{44}$ recently reported that oral exposure of mice to $\mathrm{TiO}_{2} \mathrm{NPs}$ through drinking water (50-500 mg/kg BW/day for 5 days) induced oxidative DNA damage, micronuclei formation and $\gamma$-H2AX foci, the indicators of DNA double strand breaks. Since also high-level gene expression of pro-inflammatory cytokines was also observed, the authors suggested the inflammatory effects were responsible for the induction of genotoxic effects.

The in vitro and in vivo genotoxicity studies using different experimental models indicate that nano- $\mathrm{TiO}_{2}$ may cause genotoxic effects via secondary mechanisms that include oxidative stress and inflammation. $32,38,40,43,44$ However, there is some evidence that nano-sized $\mathrm{TiO}_{2}$ can locate in nuclei ${ }^{17}$, and recently Li et al. ${ }^{45}$ reported the presence of anatase nano-sized $\mathrm{TiO}_{2}$ in DNA extracted from the liver of mice exposed intraperitoneally to these NPs (5-150 mg/kg BW/day for 14 days). The authors showed that Ti inserted between DNA base pairs or bound to DNA nucleotides, in such a way that it altered the conformation of the DNA and, at higher doses, caused DNA cleavage. These findings indicate that $\mathrm{TiO}_{2}$ may also induce genetic damage by a direct interaction with the DNA.

\section{Immunotoxic effects of $\mathrm{TiO}_{2} \mathrm{NPs}$}

Depending on physicochemical properties of NPs, they are recognized and taken up by immune cells, such as macrophages, monocytes, platelets, leukocytes and dendritic cells, and can trigger an inflammatory response. In a human monoblastoid cell line (U937) exposure to $\mathrm{TiO}_{2} \mathrm{NPs}$ induced apoptosis and necrosis in concentrations corresponding to those found in blood, plasma, or in tissues sur- rounding Ti implants ${ }^{46}$. Palomäki et al. ${ }^{47}$ reported that rutile $\mathrm{TiO}_{2} \mathrm{NPs}$ and silica-coated rutile $\mathrm{TiO}_{2}$ NPs induced the enhanced expression of a variety of proinflammatory cytokines in murine dendritic cells (bm-DC) and in murine macrophages (RAW 246.7). The particles were for dendritic cells more toxic than for macrophages. In dendritic cells nano-sized $\mathrm{TiO}_{2}$ led to an upregulation of maturation markers and activated the NLRP3 inflammasome, a multiprotein complex within the cytoplasm of antigen-presenting cells, leading to significant IL $1 \beta$-secretion. It was demonstrated for neutrophils that the short-term exposure of neutrophils to nano-anatase $\mathrm{TiO}_{2}$ induces changes in their morphology, indicating its potential to activate these cells, while longer exposure resulted in the inhibition of apoptosis and cytokine production, confirming that in vitro $\mathrm{TiO}_{2}$ exerts neutrophil agonist properties.

Immunomodulating effects after exposure to $\mathrm{TiO}_{2}$ NPs have been observed also in in vivo studies. Larsen et al. ${ }^{48}$ showed that in ovalbumin immunized mice intraperitoneal exposure to $\mathrm{TiO}_{2} \mathrm{NPs}$ promoted a T-helper type 2 cells mediated dominant immune response with high levels of ovalbumin-specific immunoglobulins $\operatorname{IgE}$ and $\operatorname{IgG1}$ in serum and influx of eosinophils, neutrophils and lymphocytes in bronchoalveolar lavage fluid. Airway inflammation and immune adjuvant activity in ovalbumin immunized mice was observed also after intranasal exposure to $\mathrm{TiO}_{2} \mathrm{NPs}{ }^{48,49}$ indicating that airborne exposure to $\mathrm{TiO}_{2}$ NPs may induce respiratory allergy, where the possible mechanism could be an adjuvant-like activity of NPs on allergic sensitization. Associated with the impairment of the immune response, recently Moon et al. ${ }^{50}$ showed that the intraperitoneal exposure of mice to $\mathrm{TiO}_{2} \mathrm{NPs}$ enhanced the growth of subcutaneously implanted B16F10 melanoma through the immunomodulation of B- and T-lymphocytes, macrophages, and natural killer cells.

\section{Neurotoxic effects of $\mathrm{TiO}_{2}$ NPs}

It has been reported that inhaled NPs can translocate to the central nervous system through the olfactory pathway ${ }^{22}$ and by crossing the bloodbrain barrier. ${ }^{51,52}$ In vitro studies of non-irradiated $\mathrm{TiO}_{2}$ NPs (Degussa P25) showed that they cause oxidative stress in the brain microglia BV2 cell line ${ }^{53}$ that was associated with the up-regulation of genes involved in the inflammation, apoptosis, and the cell cycle, and down-regulation of genes involved in energy metabolism. ${ }^{25}$ While Degussa 

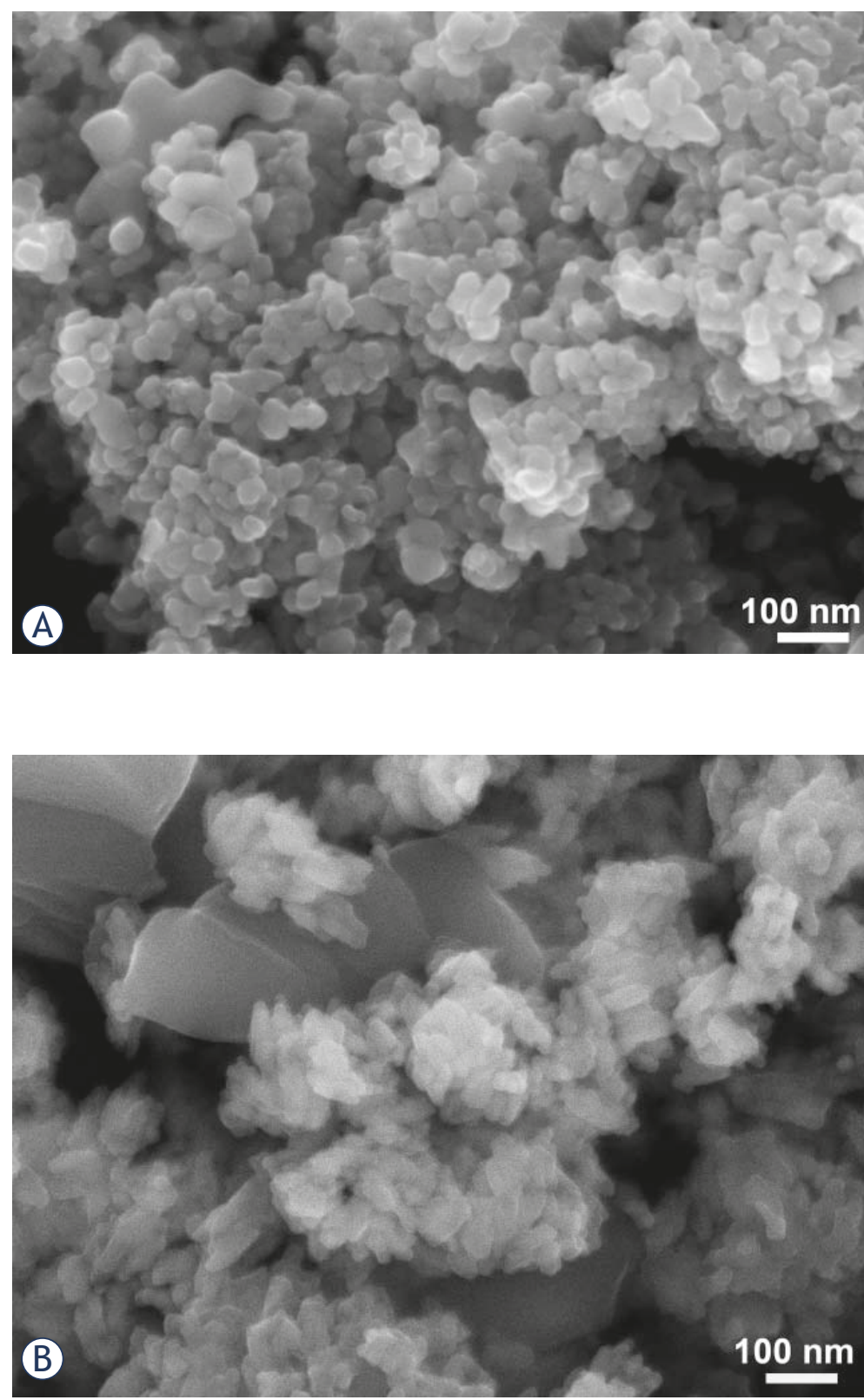

P25 NPs stimulated ROS formation in BV2 microglia, they were nontoxic to isolated N27 neurons. However, in complex brain cultures the Degussa P25 particles rapidly damaged neurons, plausibly through microglial generated ROS. In contrast, Liu et al. ${ }^{54}$ reported that, in the neuronal cell line PC12, exposure to nano- $\mathrm{TiO}_{2}$ induced dose-dependent oxidative stress and apoptosis that was partly prevented by pre-treatment with a ROS scavenger. Surprisingly, it was shown recently ${ }^{55}$ that $\mathrm{TiO}_{2} \mathrm{NPs}$ (rutile $\mathrm{TiO}_{2}$ coated with $\mathrm{SiO}_{2} ; 80-100 \mathrm{~nm}$ ) might be an inducer of the differentiation of (mouse) neural

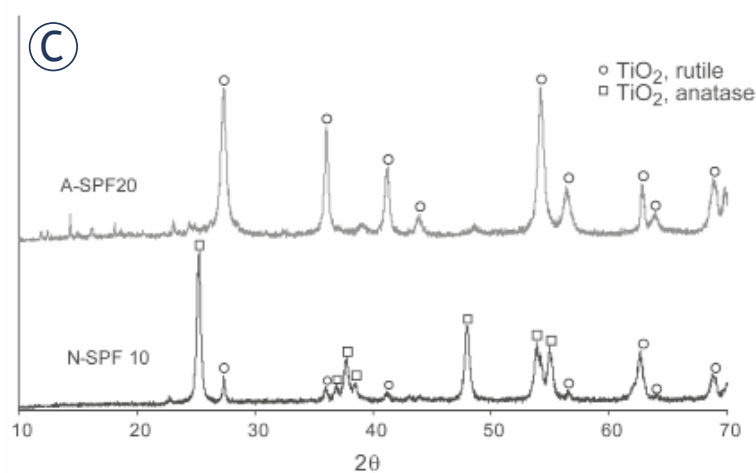

FIGURE 2. Field emission electron micrographs of the powders from two commercial sunscreens: A-SPF 20 (A) and N-SPF 10 (B), and their XRD diffraction (C).

stem cells towards neurons. These results indicate that the responses may be cell-type dependent and oxidative stress-mediated.

Recently Scuri et al. ${ }^{56}$ reported that inhalation exposure of newborn (2-day-old) and weanling (2-week-old), but not adult, rats to $\mathrm{TiO}_{2} \mathrm{NPs}$ (12 $\mathrm{mg} / \mathrm{m}^{3} ; 5.6 \mathrm{~h} /$ day for 3 days) up-regulates the expression of lung neurotrophins, key regulatory elements of neuronal development and responsiveness that play a critical role in the pathophysiology of childhood asthma. The effect was associated with the development of airway hyperreactivity (AHR) and mild airway inflammation. These results suggest the presence of a critical window of vulnerability in the earlier stages of lung development, which may lead to a higher risk of developing asthma.

\section{$\mathrm{TiO}_{2}$ NPs in everyday life}

Nano-sized $\mathrm{TiO}_{2}$ in various forms is used widely in everyday life in a variety of products, such as antifouling paints, household products, plastic goods, medications, cosmetics, sunscreens, pharmaceutical additives and food colorants, and many new applications are under development or already in pilot production. In the following sections we consider the main entry ports of nano-sized $\mathrm{TiO}_{2}$ into the human body and potential adverse effects.

\section{Dermal exposure to $\mathrm{TiO}_{2} \mathrm{NPs}$}

\section{$\mathrm{TiO}_{2} \mathrm{NPs}$ as a component of the sunscreen- technology revolution}

During recent decades, skin cancer has become the most frequent neoplastic disease among the Caucasian population in Europe, North America 
and Australia, and its incidence has reached epidemic proportions. ${ }^{57}$ As a consequence, the trend in sun protection in daily cosmetics is towards increased use of organic and inorganic UV filters. It is estimated that worldwide use of nano-sized $\mathrm{TiO}_{2}$ in sunscreens is around 1000 tons per year. ${ }^{51}$

$\mathrm{TiO}_{2}$ has been used in sunscreens since 1952, however the Food and Drug Administration (FDA) approved the use of $\mathrm{TiO}_{2}$ in sunscreens in 1999.58,59 Currently it is not required to label sunscreens as containing nano- $\mathrm{TiO}_{2}{ }^{60}$ The situation could change if the European Union (EU) commission adopts a proposed new regulation within EU Cosmetic Directive, under which all cosmetics that contain more than $1 \% \mathrm{w} / \mathrm{w}$ of NPs will have to declare it on the packaging. Since $\mathrm{TiO}_{2}$ is considered as lowirritating, it is the only inorganic UV filter allowed by European legislation in concentrations as high as $25 \% .{ }^{61,62}$ There is also some confusion regarding the classification of sunscreens. In the EU they are classified as cosmetics, while in the USA, they are classified as over the counter (OTC) drugs. ${ }^{63}$

The average size of the $\mathrm{TiO}_{2}$ particles in sunscreens ranges between 10 and $100 \mathrm{~nm}$, while some products contain particles down to $5 \mathrm{~nm}$ or up to $500 \mathrm{~nm} .{ }^{64} \mathrm{TiO}_{2}$ particles in the size range between 200 and $500 \mathrm{~nm}$ are opaque and act as a true sunblock when applied to the skin. ${ }^{61,65,66}$ However, this opacity is lost when much finer particles are used. Such sunscreens are more transparent, less viscous, and blend into the skin more easily. Therefore, the optimum size of $\mathrm{TiO}_{2}$ particles was suggested to be around $50 \mathrm{~nm}$, which provides good protection against UV light, while the dispersion of visible light is such that sunscreens do not appear white on the skin. ${ }^{67}$

Sunscreens typically, but not exclusively, contain rutile $\mathrm{TiO}_{2}$ powder, which is less photo-active than the anatase $\mathrm{TiO}_{2}$. Micrographs of the powders extracted from two commercial sunscreens from different producers are shown in Figures 2A and B. From the $\mathrm{X}$-ray diffractograms (Figure 2C) it is evident that the $\mathrm{TiO}_{2}$ powder in the sunscreen "N-SPF10" is predominantly in the anatase form, with an estimated particle size of around $50 \mathrm{~nm}$ (Figure 2A, C), while the powder in the sunscreen "A-SPF20" contained rutile $\mathrm{TiO}_{2}$ with two size populations (Figure 2B, C). (The original commercial names of the products were adapted for this study.)

To minimize the harmful effects of photo-active nano- $\mathrm{TiO}_{2}$, various coatings such as magnesia, silica, alumina or zirconia ${ }^{68-71}$ were introduced. However, certain coating materials may have side effects, such as aluminium-based ones (Figure 3),

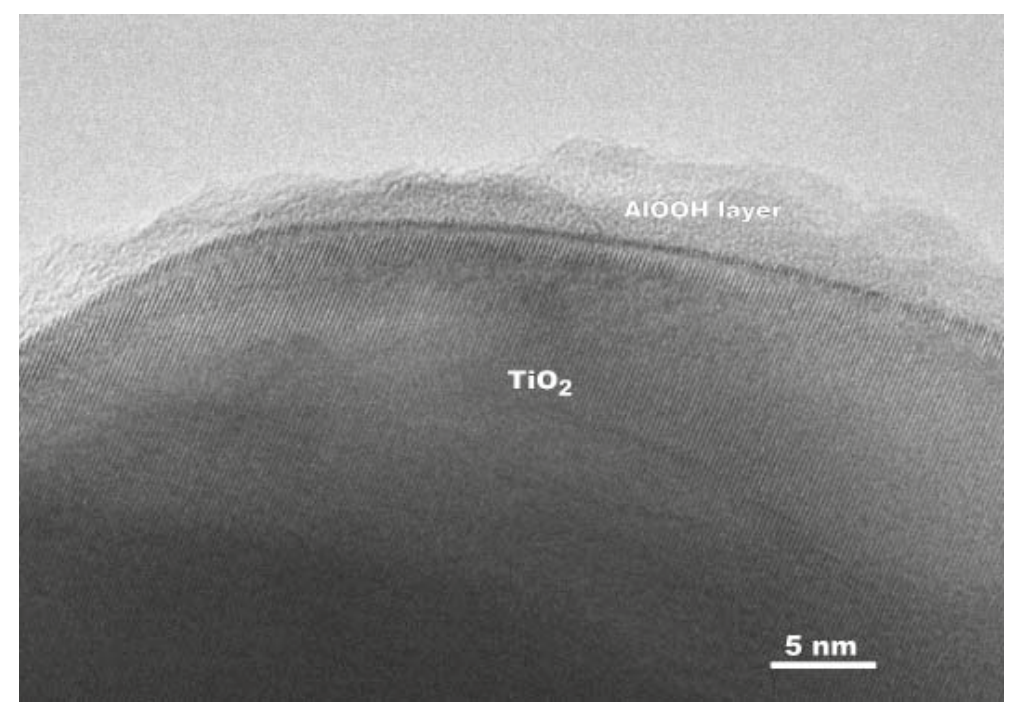

FIGURE 3. Transmission electron micrograph of an $\mathrm{AlOOH}$-coated $\mathrm{TiO}_{2} \mathrm{NP}$ (Courtesy of dr. G. Dražić).

and it is also not clear how stable the coatings are and what is the lifetime of the "inert" particle released from sunscreens.

\section{Cytotoxic and genotoxic effects of $\mathrm{TiO}_{2} \mathrm{NPs}$ in dermal cells and skin models}

Different dermal cell types have been reported to differ in their sensitivity to nano-sized $\mathrm{TiO}_{2}$. Kiss et al. ${ }^{72}$ exposed human keratinocytes (HaCaT), human dermal fibroblast cells, sebaceous gland cells (SZ95) and primary human melanocytes to $9 \mathrm{~nm}-$ sized $\mathrm{TiO}_{2}$ particles at concentrations from 0.15 to $15 \mu \mathrm{g} / \mathrm{cm}^{2}$ for up to 4 days. The particles were detected in the cytoplasm and perinuclear region in fibroblasts and melanocytes, but not in keratinocytes or sebaceous cells. The uptake was associated with an increase in the intracellular $\mathrm{Ca}^{2+}$ concentration. A dose- and time-dependent decrease in cell proliferation was evident in all cell types, whereas in fibroblasts an increase in cell death via apoptosis has also been observed. Anatase $\mathrm{TiO}_{2}$ in 20-100 nm-sized form has been shown to be cytotoxic in mouse L929 fibroblasts. ${ }^{73}$ The decrease in cell viability was associated with an increase in the production of ROS and the depletion of glutathione. The particles were internalized and detected within lysosomes. In human keratinocytes exposed for $24 \mathrm{~h}$ to non-illuminated, $7 \mathrm{~nm}$-sized anatase $\mathrm{TiO}_{2}$, a cluster analysis of the gene expression revealed that genes involved in the "inflammatory response" and "cell adhesion", but not those involved in "oxidative stress" and "apoptosis", were up-regulated. ${ }^{73}$ The results suggest that non-illu- 
minated $\mathrm{TiO}_{2}$ particles have no significant impact on ROS-associated oxidative damage, but affect the cell-matrix adhesion in keratinocytes in extracellular matrix remodelling. In human keratinocytes, Kocbek et al. ${ }^{19}$ investigated the adverse effects of $25 \mathrm{~nm}$-sized anatase $\mathrm{TiO}_{2}(5$ and $10 \mu \mathrm{g} / \mathrm{ml})$ after 3 months of exposure and found no changes in the cell growth and morphology, mitochondrial function and cell cycle distribution. The only change was a larger number of nanotubular intracellular connections in $\mathrm{TiO}_{2}$-exposed cells compared to non-exposed cells. Although the authors proposed that this change may indicate a cellular transformation, the significance of this finding is not clear. On the other hand, Dunford et al..$^{23}$ studied the genotoxicity of UV-irradiated $\mathrm{TiO}_{2}$ extracted from sunscreen lotions, and reported severe damage to plasmid and nuclear DNA in human fibroblasts. Manitol (antioxidant) prevented DNA damage, implying that the genotoxicity was mediated by ROS.

Recently, Yanagisawa et al. ${ }^{74}$ reported that the transdermal exposure (mimicking skin-barrier dysfunction or defect) of $\mathrm{NC} / \mathrm{Nga}$ mice to $\mathrm{TiO}_{2} \mathrm{NPs}$ $(15,50$, or $100 \mathrm{~nm})$, in combination with allergen, aggravated atopic dermatitis-like lesions through a T-helper type 2 (Th2) dominant immune response. The study also indicated that $\mathrm{TiO}_{2} \mathrm{NPs}$ can play a role in the initiation and/or progression of skin diseases, since histamine was released, even in the absence of allergen.

\section{Skin-penetration studies}

The skin of an adult person is, in most places, covered with a relatively thick $(\sim 10 \mu \mathrm{m})$ barrier of keratinised dead cells. One of the main questions is still whether $\mathrm{TiO}_{2}$ NPs are able to penetrate into the deeper layers of the skin. ${ }^{75}$ The majority of studies suggest that $\mathrm{TiO}_{2} \mathrm{NPs}$, neither uncoated nor coated $\left(\mathrm{SiO}_{2}, \mathrm{Al}_{2} \mathrm{O}_{3}\right.$ and $\left.\mathrm{SiO}_{2} / \mathrm{Al}_{2} \mathrm{O}_{3}\right)$ of different crystalline structures, penetrate normal animal or human skin. ${ }^{6,77-82}$ However, in most of these studies the exposures were short term (up to $48 \mathrm{~h}$ ); only few long-term or repeated exposure studies have been published. Wu et al. ${ }^{83}$ have shown that dermal application of nano- $\mathrm{TiO}_{2}$ of different crystal structures and sizes $(4-90 \mathrm{~nm})$ to pig ears for 30 days did not result in penetration of NPs beyond deep epidermis. On the other hand, in the same study the authors reported dermal penetration of $\mathrm{TiO}_{2}$ NPs with subsequent appearance of lesions in multiple organs in hairless mice, that were dermal exposed to nano- $\mathrm{TiO}_{2}$ for 60 days. However, the relevance of this study for human exposure is not conclusive because hairless mice skin has abnormal hair follicles, and mice stratum corneum has higher lipid content than human stratum corneum, which may contribute to different penetration. Recently Sadrieh et al. ${ }^{84}$ performed a 4 week dermal exposure to three different $\mathrm{TiO}_{2}$ particles (uncoated submicron-sized, uncoated nano-sized and coated nano-sized) in $5 \%$ sunscreen formulation with minipigs. They found elevated titanium levels in epidermis, dermis and in inguinal lymph nodes, but not in precapsular and submandibular lymph nodes and in liver. With the energy dispersive $\mathrm{X}$-ray spectrometry and transmission electron microscopy (TEM) analysis the authors confirmed presence of few $\mathrm{TiO}_{2}$ particles in dermis and calculated that uncoated nano-sized $\mathrm{TiO}_{2}$ particles observed in dermis represented only $0.00008 \%$ of the total applied amount of $\mathrm{TiO}_{2}$ particles. Based on the same assumptions used by the authors in their calculations it can be calculated that the total number of particles applied was $1.8 \times 10^{13} / \mathrm{cm}^{2}$ and of these $1.4 \times 10^{7} / \mathrm{cm}^{2}$ penetrated. The surface area of skin in humans is around $1.8 \mathrm{~m}^{285}$ and for sun protection the cream is applied over whole body, which would mean that 4 week usage of such cream with $5 \% \mathrm{TiO}_{2}$ would result in penetration of totally 2.6 $\times 10^{10}$ particles. Although Sadrieh et al. ${ }^{84}$ concluded that there was no significant penetration of $\mathrm{TiO}_{2}$ NPs through intact normal epidermis, the results are not completely confirmative.

\section{$\mathrm{TiO}_{2}$ NPs intake by food}

$\mathrm{TiO}_{2}$ has been well accepted in the food industry and can be found as the E171 additive in various food products, mainly for whitening and texture. It is present in some cottage and Mozzarella cheeses, horseradish cream and sauces, lemon curd, and in low-fat products such as skimmed milk and icecream. Even if the product is labelled as containing E171, no information is usually given about the quantity, particle size and particle structure. FDA claims that $\mathrm{TiO}_{2}$ may be safely used as a colour additive for colouring foods in quantities up to $1 \%$ by weight of the food. ${ }^{86}$ Interestingly, $\mathrm{TiO}_{2}$ is frequently declared as a "natural colouring agent" and is therefore well accepted by consumers.

$\mathrm{TiO}_{2}$ is also used in oral pharmaceutical formulations ${ }^{5}$, and the Pharmaceutical Excipients handbook considers nano-sized $\mathrm{TiO}_{2}$ a non-irritant and non-toxic excipient. Despite the fact that $\mathrm{TiO}_{2}$ submicron- and nano-sized particles are widely used as food and pharmaceutical additives, information 
on their toxicity and distribution upon oral exposure is very limited.

\section{Potential hazards of oral exposure to $\mathrm{TiO}_{2} \mathrm{NPs}$}

The gastrointestinal tract is a complex barrier/exchange system, and is the most important route by which macromolecules can enter the body. The main absorption takes place through villi and microvilli of the epithelium of the small and large intestines, which have an overall surface of about $200 \mathrm{~m}^{2}$. Already in 1922, it was recognized by $\mathrm{Kumagai}^{87}$, that particles can translocate from the lumen of the intestinal tract via aggregation of intestinal lymphatic tissue (Peyer's patch , containing M-cells (phagocytic enterocytes)). Uptake can also occur via the normal intestinal enterocytes. Solid particles, once in the sub-mucosal tissue, are able to enter both the lymphatic and blood circulation.

In an early study Jani et al..$^{88}$ administred rutile $\mathrm{TiO}_{2}(500 \mathrm{~nm})$ as a $0.1 \mathrm{ml}$ of $2.5 \% \mathrm{w} / \mathrm{v}$ suspension (12.5 mg/kg BW) to female Sprague Dawley rats, by oral gavage daily for 10 days and detected presence of particles in all the major gut associated lymphoid tissue as well as in distant organs such as the liver, spleen, lung and peritoneal tissue, but not in heart and kidney. The distribution and toxicity of nano- $(25 \mathrm{~nm}, 80 \mathrm{~nm})$ and submicron-sized $(155 \mathrm{~nm}) \mathrm{TiO}_{2}$ particles were evaluated in mice administered a large, single, oral dosing ( $5 \mathrm{~g} / \mathrm{kg} \mathrm{BW})$ by gavage. ${ }^{89}$ In the animals that were sacrificed two weeks later, ICP-MS analysis showed that the particles were retained mainly in liver, spleen, kidney, and lung tissues, indicating that they can be transported to other tissues and organs after uptake by the gastrointestinal tract. Interestingly, although an extremely high dose was administrated, no acute toxicity was observed. In groups exposed to $80 \mathrm{~nm}$ and $155 \mathrm{~nm}$ particles, histopathological changes were observed in the liver, kidney and in the brain. The biochemical serum parameters also indicated liver, kidney and cardiovascular damage and were higher in mice treated with nano-sized (25 or $80 \mathrm{~nm}$ ) $\mathrm{TiO}_{2}$ compared to submicron-sized $(155 \mathrm{~nm}) \mathrm{TiO}_{2}$. However, the main weaknesses of this study are the use of extremely high single dose and insufficient characterisation of the particles.

Duan et al. ${ }^{90}$ administered $125 \mathrm{mg} / \mathrm{kg}$ BW or 250 $\mathrm{mg} / \mathrm{kg} \mathrm{BW}$ of anatase $\mathrm{TiO}_{2}(5 \mathrm{~nm})$ intragastrically to mice continuously for 30 days. The exposed mice lost body weight, whereas the relative liver, kidney, spleen and thymus weights increased. Particles seriously affected the haemostasis of the blood and the immune system. The decrease in the immune response could be the result of damage to the spleen, which is the largest immune organ in animals and plays an important role in the immune response. Powel et al. ${ }^{91}$ demonstrated that $\mathrm{TiO}_{2} \mathrm{NPs}$ may trigger immune reactions of the intestine after oral intake. They showed that $\mathrm{TiO}_{2} \mathrm{NPs}$ conjugated with bacterial lipopolysaccharide, but not $\mathrm{TiO}_{2} \mathrm{NPs}$ or lipopolysaccharide alone, trigger the immune response in human peripheral blood mononuclear cells and in isolated intestinal tissue. This indicates that $\mathrm{TiO}_{2} \mathrm{NPs}$ may be important mediators in overcoming normal gut-cell hyporesponsiveness to endogenous luminal molecules, which may be particularly relevant to patients with inflammatory bowel disease, which is characterized by an abnormal intestinal permeability.

The National Cancer Institute tested $\mathrm{TiO}_{2}$ for possible carcinogenicity by the oral route of exposure by feeding rats and mice with $\mathrm{TiO}_{2}$ (size not specified) at doses 25,000 or $50,000 \mathrm{ppm} \mathrm{TiO}_{2}$ for 103 weeks. They concluded that $\mathrm{TiO}_{2}$ was not carcinogenic. ${ }^{92}$ Also, the study with rats fed diets containing up to $5 \% \mathrm{TiO}_{2}$ coated mica for 130 weeks showed no treatment-related carcinogenicity. ${ }^{93}$ Since the size and other $\mathrm{TiO}_{2}$ properties were not specified or determined, we cannot generalize this conclusion and we have to take into account other possible outcomes of this scenario in different exposure conditions (other size/crystalline structure of $\mathrm{TiO}_{2}$ etc.).

It should also be considered that due to the low $\mathrm{pH}$ in the stomach, the increased dissolution of the $\mathrm{TiO}_{2}$ particles may increase its bioavailability and may facilitate the entry of titanium ions into the blood circulation. ${ }^{94}$ Despite the relatively large consumption of $\mathrm{TiO}_{2}$ as a food additive, no studies on the effect of $\mathrm{pH}$ on its absorption and bioavailability have been found in the literature. This can be attributed to a general belief that $\mathrm{TiO}_{2}$ is completely insoluble. However, this is not completely true, as $\mathrm{TiO}_{2}$ particles show a certain degree of solubility. ${ }^{33}$

\section{Exposure to $\mathrm{TiO}_{2} \mathrm{NPs}$ by inhalation}

Inhalation exposure to $\mathrm{TiO}_{2}$ particles occurs predominantly in occupational settings during production of $\mathrm{TiO}_{2}$ powders and manufacturing the products containing $\mathrm{TiO}_{2}{ }^{95}$ The highest levels of exposure occur during packing, milling and site cleaning however, the empirical data regarding airborne $\mathrm{TiO}_{2}$ particle concentrations in occupational settings is very limited. Fryzek et al. ${ }^{96}$ reported that packers, micronizers and addbackes had the highest $\mathrm{TiO}_{2}$ exposure levels measuring $6.2 \pm 9.4 \mathrm{mg} / \mathrm{m}^{3}$, whereas ore handlers had lower $\mathrm{TiO}_{2}$ exposure lev- 
el of $1.1 \pm 1.1 \mathrm{mg} / \mathrm{m}^{3}$. Boffetta et al. ${ }^{97}$ reported that the yearly averaged estimated exposure to $\mathrm{TiO}_{2}$ dust in EU factories varied from 0.1 to $1.0 \mathrm{mg} / \mathrm{m}^{3}$, and the average levels ranged up to $5 \mathrm{mg} / \mathrm{m}^{3}$ for individual job categories. However, in these studies the particle size distribution has not been determined. Nevertheless, the data indicate that in certain jobs categories the exposure exceed the values of time-weighted average (10 h TWA) concentrations of $2.4 \mathrm{mg} / \mathrm{m}^{3}$ for submicron-sized $\mathrm{TiO}_{2}$ and $0.3 \mathrm{mg} / \mathrm{m}^{3}$ for nano-sized $\mathrm{TiO}_{2}$, which are recommended as exposure limits by National Institute for Occupational Safety and Health (NIOSH). ${ }^{98}$

\section{Potential hazards of inhalation exposure to $\mathrm{TiO}_{2}$ NPs}

The lung consists of about $2300 \mathrm{~km}$ of airways and 300 million alveoli. The epithelium of airways is protected by a viscous layer of mucus, and is a relatively robust barrier. In alveoli, the barrier between the alveolar wall and the capillaries is very thin, about $0.5 \mu \mathrm{m}$. Thus, the large surface area of the alveoli and the intense air-blood contact in this region makes the alveoli less protected against environmental damage than other parts of the respiratory system. ${ }^{75}$ The clearance of particles from the upper airways is achieved through the mucociliary escalator, while clearance from the deep lung is supposed to be achieved predominantly by macrophage phagocytosis. Deposited particles can lead to the activation of cytokine production and inflammation by macrophages and epithelial cells. It has been reported that besides the pulmonary and systemic inflammation, inhaled insoluble NPs can also accelerate atherosclerosis and alter the cardiac autonomic function. ${ }^{99-102}$

Following administration of nano-sized $\mathrm{TiO}_{2}$ to rats by inhalation the particles were detected in the cytoplasm of all lung-cell types in a non-membrane bound manner. ${ }^{17}$ Ferin et al. ${ }^{103}$ reported that $20 \mathrm{~nm}$ sized $\mathrm{TiO}_{2}$ particles penetrate more easily into the pulmonary interstitial space of rats than $250 \mathrm{~nm}$ sized $\mathrm{TiO}_{2}$ particles. Three-month inhalation exposure in rats demonstrated that the clearance of $20 \mathrm{~nm} \mathrm{TiO}_{2}$ particles was significantly slower than that of $200 \mathrm{~nm} \mathrm{TiO}$, particles, and more particles translocated to interstitial sites and regional lymph nodes. ${ }^{104}$ Geiser et al. ${ }^{14}$ confirmed that alveolar macrophages were not primarily responsible for the uptake and clearance of $\mathrm{TiO}_{2}$ NPs. These findings are in agreement with the known size limitations of uptake processes such as phagocytosis, which is thought to be restricted to particles that are 1 to
$5 \mu \mathrm{m}$ in size, while NPs might escape macrophage phagocytosis. ${ }^{101,105}$

Inhaled $\mathrm{TiO}_{2}$ NPs can enter the alveoli of the lung and consequently the blood circulation ${ }^{106,107}$ and can then translocate to other organs. ${ }^{102,108,109}$ In addition to several reports on the absence of toxicity following the inhalation of $\mathrm{TiO}_{2} \mathrm{NPs}$ in rodents, the majority of lung-inhalation and instillation studies have pointed out obvious toxic effects, like inflammation and damage to pulmonary epithelium. ${ }^{110}$ The studies also showed that $\mathrm{TiO}_{2}$ NPs induced greater pulmonary inflammation and tissue damage than an equal dose of submicron-sized $\mathrm{TiO}_{2}$ particles. The greater toxicity of $\mathrm{TiO}_{2} \mathrm{NPs}$ has been explained as being related to their larger surface area and their increased internalization. ${ }^{111}$ Multiple studies showed the reversibility of the inflammatory response after cessation of the exposure to $\mathrm{TiO}_{2}$ particles. After a single instillation exposure to different types of submicron- and nanosized $\mathrm{TiO}_{2}$, acute inflammatory response returned to control levels within one week ${ }^{112}$ or 90 days $^{113}$ after the instillation. In mice that were exposed to $\mathrm{TiO}_{2}$ NPs (2-5 nm) by whole body inhalation $(0.77$ or $7.22 \mathrm{mg} / \mathrm{m}^{3} 4 \mathrm{~h} /$ day 10 days) the recovery was observed during the third week after exposure. ${ }^{114}$

Pulmonary toxicity studies suggest that, besides the particle size and surface area, crystal structure and surface treatment are also important parameters. Warheit et al. ${ }^{115}$ demonstrated higher pulmonary toxicity of anatase than rutile $\mathrm{TiO}_{2} \mathrm{NPs}$. These observations were confirmed in a recent study by Roursgaard et al. ${ }^{116}$ who showed that the intratracheal instillation of submicron- and nano-sized rutile, nano-sized anatase, or amorphous $\mathrm{TiO}_{2}$ to mice induced a dose-dependent acute inflammation, while subchronic inflammation was apparent only in mice exposed to nano-sized rutile and amorphous $\mathrm{TiO}_{2}$.

Recently, toxicogenomic studies were published that may contribute to a better understanding of the mechanisms of $\mathrm{TiO}_{2}$-mediated pulmonary toxicity. In mice exposed to a single intratracheal dose ( 0.1 or $0.5 \mathrm{mg} / \mathrm{kg} \mathrm{BW}$ ) of $\mathrm{TiO}_{2}$ with an average particle size of $20 \mathrm{~nm}$ Chen et al. ${ }^{117}$ showed that changes in the morphology and histology of the lungs were associated with the differential expression of hundreds of genes, including those involved in cell cycle regulation, apoptosis, chemokines, and complement cascades. In particular, $\mathrm{TiO}_{2} \mathrm{NPs}$ upregulated the expression of the placenta growth factor and other chemokines that are associated with pulmonary emphysema and alveolar epithelial cell apoptosis. Park et al. ${ }^{118}$ showed that exposure of mice 
to nano-sized $\mathrm{TiO}_{2}(5-50 \mathrm{mg} / \mathrm{kg} \mathrm{BW})$ by a single intratracheal instillation can, in addition to chronic inflammation, also trigger an autoimmune response. They found that many classes of genes related to antigen presentation and the induction of chemotaxis of immune cells were over-expressed.

The studies have shown that submicron-sized $\mathrm{TiO}_{2}{ }^{119}$ and nano-sized $\mathrm{TiO}_{2}{ }^{120,121}$ induce lung tumors in chronically exposed rats. $\mathrm{TiO}_{2} \mathrm{NPs}$ induced a significantly increased number of lung tumors during inhalation exposure to $10 \mathrm{mg} / \mathrm{m}^{3}(18 \mathrm{~h} /$ day, 2 years), while submicron-sized $\mathrm{TiO}_{2}$ increased the number of lung tumors at exposure to $250 \mathrm{mg} / \mathrm{m}^{3}$ (6 h/day 2 years). In contrast, no tumours were observed in similarly exposed mice and hamsters. ${ }^{121,122}$ These apparent species differences suggest that the experimentally induced lung tumours may be a rat-specific, threshold phenomenon, depending on lung overloading accompanied by chronic inflammation to exert the observed tumorigenic response. Comparative toxicological studies of the development and possible progression of the lung response in rats, mice and hamsters exposed to a range of concentrations of submicron- or nanosized $\mathrm{TiO}_{2}$ over a period of 90 days showed distinct species differences in the lung responses. Rats and mice had similar lung burdens and clearance rates, while hamsters showed higher clearance rates. At high lung-particle burdens, rats showed a marked progression of the histopathological lesions during the post-exposure period, while mice and hamsters showed minimal initial lesions with apparent recovery during the post-exposure period. ${ }^{123,124}$ It has been thus argued that the dose response data from inhalation studies in rats should not be used when extrapolating the cancer risk to humans. ${ }^{95}$ However, clearance of insoluble particles is in humans slower than in rats. ${ }^{125}$ In addition, it has been shown that the lung-tumour response to exposure to non-soluble particles can be predicted by the particle surface area dose without the need to account for overloading. ${ }^{98}$ Therefore, for workers with a high dust exposure the doses that cause overloading in rats may be relevant for estimating the health risk for humans.

Animal studies showed also other adverse effects after inhalation exposure to $\mathrm{TiO}_{2}$ particles. Nurkiewicz et al. ${ }^{109}$ showed that exposure to $\mathrm{TiO}_{2}$ particles may cause cardiovascular effects at concentrations below those causing adverse pulmonary effects. In rats exposed to submicron-sized $\mathrm{TiO}_{2}(<1 \mu \mathrm{m})$ or nano-sized $\mathrm{TiO}_{2}(21 \mathrm{~nm})$ at airborne exposures aimed at achieving similar particle mass deposition in the lungs (nano-sized: $1.5-12 \mathrm{mg} / \mathrm{m}^{3}$,
240-720 min; submicron-sized: $3-15 \mathrm{mg} / \mathrm{m}^{3}$, 240-480 $\mathrm{min}$ ) they observed systemic microvessel dysfunction in the absence of pulmonary inflammation or lung damage. The effect was related to the adherence of polymorphonuclear leukocytes to the microvessel walls and the production of ROS in the microvessels. As already described previously, inhalation exposure to $\mathrm{TiO}_{2} \mathrm{NPs}$ may cause immune responses and neurotoxic effects that may lead to respiratory allergy and higher risk of developing asthma, respectively.

It has been reported that $\mathrm{TiO}_{2} \mathrm{NPs}$ can translocate to the central nervous system following nasal instillation, potentially via the olfactory bulb, and accumulate mainly within the cerebral cortex, thalamus and hippocampus.22,29,126 The absorption appears to occur via neuronal transport, bypassing the blood-brain barrier. ${ }^{29,126}$ The main target is the hippocampus, where $\mathrm{TiO}_{2}$ NPs caused morphological alteration and the loss of neurones. In addition, $\mathrm{TiO}_{2}$ induced oxidative stress and an inflammatory response within the whole brain, with anatase nano- $\mathrm{TiO}_{2}$ inducing a stronger inflammatory response than rutile. However, from these studies it is not clear to what extent large local doses during nasal instillation reflect inhalation exposure.

\section{Human epidemiological studies}

Several case reports described adverse health effects in workers with potential $\mathrm{TiO}_{2}$ exposure that later lead to epidemiological studies of a relationship between occupational exposure and observed cases. ${ }^{98}$ The lung particle analyses indicated that workers exposed to respirable $\mathrm{TiO}_{2}$ had particle retention in their lungs that included $\mathrm{TiO}_{2}$, silica, and other minerals, sometimes years after cessation of exposure. In most cases of tissue-deposited $\mathrm{TiO}_{2}$ was associated with a local macrophage response and fibrosis that was generally mild. In one case papillary adenocarcinoma and $\mathrm{TiO}_{2}$ associated pneumoconiosis was reported in the lung of a 53-year-old male who had been engaged in packing $\mathrm{TiO}_{2}$ for about 13 years and had 40 -year smoking history. ${ }^{127}$ The cohort epidemiological studies undertaken in the USA ${ }^{96,128}$ did not report excess risks of lung cancer; nor did a Canadian population-based case-control study. ${ }^{129}$ The retrospective cohort lung cancer mortality study ${ }^{130}$, which included workers in the $\mathrm{TiO}_{2}$ production industry in six European countries, showed a small but significant elevation in lung cancer mortality among male $\mathrm{TiO}_{2}$ workers when compared to the general 
population. However, the data did not suggest an exposure-response relation.

$\mathrm{TiO}_{2}$ has been classified by the International Agency for Research on Cancer (IARC) as an IARC Group 2B carcinogen, "possibly carcinogenic to humans" by inhalation. ${ }^{131}$ Although the IARC working group concluded that the epidemiological studies on $\mathrm{TiO}_{2}$ provide inadequate evidence of carcinogenicity, they considered that the results from animal studies of inhalation and intratracheal instillation provide sufficient evidence to classify $\mathrm{TiO}_{2}$ in Group 2B. ${ }^{132}$ Also NIOSH ${ }^{98}$ has recently classified $\mathrm{TiO}_{2} \mathrm{NPs}$ as a potential occupational carcinogen but considered that there is insufficient evidence at this time to classify also submicronsized $\mathrm{TiO}_{2}$ as a potential occupational carcinogen. NIOSH also recommended new exposure limits at $2.4 \mathrm{mg} / \mathrm{m}^{3}$ for submicron-sized $\mathrm{TiO}_{2}$ and $0.3 \mathrm{mg} / \mathrm{m}^{3}$ for nano-sized $\mathrm{TiO}_{2}$, as time-weighted average concentrations for up to 10 hours per day during a 40-hour work week.

\section{Exposure to $\mathrm{TiO}_{2}$ NPs through body implants}

A few-nanometres-thick layer of amorphous $\mathrm{TiO}_{2}$ is commonly formed on the surface of orthopaedic and dental implants made of titanium metal or its alloys. In non-moving implants (hip stems, plates, screws, etc.) this does not appear to represent the same kind of risk for the body as free $\mathrm{TiO}_{2}$ NPs discussed in previous sections. However, this is not the case for wear-exposed implants, such as hip and knee joints. There are many reports proving that under mechanical stress or altered physiological conditions, Ti-based implants can release biologically relevant amounts of debris, in both the micrometre and nanometre ranges, that can migrate to the surrounding tissues. During the wear process, a thin amorphous oxide layer is continuously being created and removed, resulting in large numbers of titanium particles. It is increasingly being suggested that they are associated with major inflammation and systemic diseases. ${ }^{133}$ Furthermore, increasing numbers of reports indicate that the delayed hypersensitivity to titanium and its oxides may constitute a health risk for individuals with higher susceptibility. ${ }^{134-136}$

The effects of the $\mathrm{TiO}_{2}$ particles released from implants were investigated by Wang et al. ${ }^{137}$ in rats by intra-articular injection of 0.2 to $20 \mathrm{mg}$ of anatase nano- $\mathrm{TiO}_{2}$ per $\mathrm{kg} \mathrm{BW}$. Their results demonstrate that particles can potentially affect major organs like the heart, lung and liver.
Generally, the maximum diameter of particles that move across the synovial capillary wall was suggested to be $50 \mathrm{~nm}$. The released $\mathrm{TiO}_{2} \mathrm{NPs}$ resulted in synovial hypotrophy, lymphocyte and plasma infiltration, and fibroblast proliferation in the knee joint. Oxidative stress and lipid peroxidation was detected in exposed synovial fluid. Seven days after the initial exposure a brown particulate deposit was observed in vascular endothelial cells and in alveolar macrophages. Similar results have been reported by Urban et al. ${ }^{138}$, who found $\mathrm{TiO}_{2}$ particles in the liver and in the spleen of the patients with implants. $\mathrm{TiO}_{2} \mathrm{NPs}$ were observed in joint simulators and in joint periprosthetic tissues. Margevicius et al. ${ }^{139}$ characterized the debris around the total hip joint prosthesis and found up to $140.10^{9}$ particles/g dry weight, in diameters ranging from 0.58 to 100 $\mu \mathrm{m}$. Agins et al. ${ }^{140}$ found concentration of wear particles in the tissue adjacent to a prosthesis in the range between $56 \mu \mathrm{g} / \mathrm{g}$ and $3.7 \mathrm{mg} / \mathrm{g}$ dry weight. Thus, due to the natural tendency of titanium to oxidise, Ti-based implants should not be neglected as a possible source of $\mathrm{TiO}_{2}$ exposure.

On the other hand, the man-made (crystalline) $\mathrm{TiO}_{2}$ coatings on the surfaces of pure Ti or Ti alloys are reported to be able to modulate protein absorption, cell adhesion, osseointegration and bone mineralization at the bone-biomaterial interface, both in vivo and in vitro. ${ }^{141,142}$ For this reason, the development of a more stable crystalline titania coating on Ti-based implants is in progress. ${ }^{143}$

\section{Environmental pollution by $\mathrm{TiO}_{2} \mathrm{NPs}$}

Toxic effects of $\mathrm{TiO}_{2} \mathrm{NPs}$ on aquatic organisms

The trend in the production of NPs is likely to lead to increasing amounts of nano-powders in the air, water and soil, which will consequently affect living organisms. Labielle et al. ${ }^{68}$ demonstrated that $25 \%$ of $\mathrm{Al}(\mathrm{OH})_{3}$-coated $\mathrm{TiO}_{2}$ particles from sunscreens are dispersed as a stable colloid and become available to microorganisms and filterfeeders, while the remaining $75 \%$ are probably incorporated into geogenic sediments, where they could become available to benthic fauna. Solar UV iradiation may penetrate as far as $20 \mathrm{~m}$ in the water column ${ }^{144}$ and therefore photo-activate the dispersed particles, which may have an adverse effect on various aquatic organisms.

Freshwater algae show low-to-moderate susceptibility to $\mathrm{TiO}_{2}$ exposure, with more pronounced 
toxic effects in the presence of UV irradiation. It has also been shown that nano-sized $\mathrm{TiO}_{2}$ is significantly more toxic to algae Pseudokirchneriella subcapitata than submicron-sized $\mathrm{TiO}_{2} \cdot{ }^{145}$ Hund-Rinke and Simon ${ }^{146}$ reported that UV irradiated $25 \mathrm{~nm}$ $\mathrm{TiO}_{2}$ NPs are more toxic to green freshwater algae Desmodesmus subspicatus than UV irradiated $50 \mathrm{~nm}$ particles, which is in agreement with Hartmann et al. ${ }^{147}$ UV irradiated $\mathrm{TiO}_{2} \mathrm{NPs}$ also inactivated other algae species such as Anabaena, Microcystis, Melsoira ${ }^{148}$ and Chroococcus. ${ }^{149}$ It was demonstrated that smaller particles have a greater potential to penetrate the cell interior than submicron-sized particles and larger aggregates. Studies have shown that the amount of $\mathrm{TiO}_{2}$ adsorbed on algal cells can be up to 2.3 times their own weight. ${ }^{142}$

Nano-sized $\mathrm{TiO}_{2}$ generally shows low or no acute toxicity in both invertebrates ${ }^{146}$ and vertebrates. ${ }^{150}$ However, exposure of Daphnia magna to $20 \mathrm{ppm} \mathrm{TiO}_{2}$ for 8 consecutive days was found to cause $40 \%$ mortality. ${ }^{151} \mathrm{Zhu}$ et al. ${ }^{152}$ showed minimal toxicity to D. magna after $48 \mathrm{~h}$ exposure, while upon chronic exposure for 21 days, D. magna suffered severe growth retardation and mortality. A significant amount of nano-sized $\mathrm{TiO}_{2}$ was found also accumulated in the body of the animals. Similar findings with coated nano-sized $\mathrm{TiO}_{2}$ (T-Lite ${ }^{\mathrm{TM}} \mathrm{SF}$, T-Lite ${ }^{\mathrm{TM}}$ SF-S and T-Lite ${ }^{\mathrm{TM}}$ MAX; BASF SE) were reported by Wiench et al. ${ }^{153}$ Biochemical measurements showed that exposure to $\mathrm{TiO}_{2} \mathrm{NPs}$ induces significant concentration-dependent antioxidant enzyme activities in D. magna ${ }^{154}$. Lee et al. ${ }^{155}$ showed that 7 and $20 \mathrm{~nm}$-sized $\mathrm{TiO}_{2}$ induced no genotoxic effect in D. magna and in the larva of the aquatic midge Chironomus riparius.

No acute effects of nano-sized $\mathrm{TiO}_{2}$ were observed in Danio rerio (zebrafish) embryos. ${ }^{156}$ Exposure of rainbow trout to $\mathrm{TiO}_{2} \mathrm{NPs}$ triggered lipid peroxidation, influence on the respiratory tract, disturbance in the metabolism of $\mathrm{Cu}$ and $\mathrm{Zn}$, induction of intestinal erosion ${ }^{157}$ and accumulation in kidney tissue. ${ }^{158}$ Linhua et al. ${ }^{159}$ exposed juvenile carp to 100 and $200 \mathrm{mg} / \mathrm{ml}$ of $\mathrm{TiO}_{2}$ particles and observed no mortality. However, the fish suffered from oxidative stress and pathological changes in gill and liver. In the infaunal species Arenicola marina, exposure to $\mathrm{TiO}_{2} \mathrm{NPs}$ in sediment caused sub-lethal effects including decrease in casting rate and increase in cellular and DNA damage. ${ }^{160}$ Aggregated particles were visible in the lumen of the gut, but no uptake through the gut or the skin was observed.

Zhu et al..$^{161}$ were the first to provide evidence that $\mathrm{TiO}_{2} \mathrm{NPs}(21 \mathrm{~nm})$ can transfer from daphnia to zebrafish by dietary exposure. Hence, dietary intake could be a major route of exposure to NPs for high trophic level aquatic organisms. Ecological research should therefore focus, not only on the concentration of NPs in the environment, but also on its bioconcentration, bioaccumulation and biomagnification. In addition it has been shown that $\mathrm{TiO}_{2}$ NPs can increase accumulation of other environmental toxicants: enhanced accumulation of cadmium (Cd) and arsenic (As) was found in carp in the presence of $\mathrm{TiO}_{2} \mathrm{NPs}^{162,163}$ The strong adsorption capacity for $\mathrm{Cd}$ and As was explained by the large specific surface area and strong electrostatic attraction of $\mathrm{TiO}_{2} \mathrm{NPs}$ that contribute to facilitated transport into different organs.

In vitro, in the hemocytes of the marine mussel Mytilus hemocytes, suspension of $\mathrm{TiO}_{2} \mathrm{NPs}$ (Degussa P25, $10 \mu \mathrm{g} / \mathrm{ml}$ ) stimulated immune and inflammatory responses, such as lysozyme release, oxidative burst and nitric oxide production. ${ }^{164}$ Vevers and Jha ${ }^{165}$ demonstrated the intrinsic genotoxic and cytotoxic potential of $\mathrm{TiO}_{2}$ NPs on a fish-cell line derived from rainbow-trout gonadal tissue (RTG2 cells) after $24 \mathrm{~h}$ of exposure to $50 \mu \mathrm{g} / \mathrm{ml}$. Reeves et al. ${ }^{166}$ demonstrated a significant increase in the level of oxidative DNA damage in goldfish cells, and suggested that damage could not repaired by DNA repair mechanisms. Another suggestion from the mentioned study was that hydroxyl radicals are generated also in the absence of UV light. It has been shown that fish cells are generally more susceptible to toxic/oxidative injury than mammalian cells.

\section{Toxic effects of $\mathrm{TiO}_{2}$ NPs on soil organisms}

Drobne et al. ${ }^{167}$ used the terrestrial arthropod Porcellio scaber as a test organism for determining the cytotoxic effect of $\mathrm{TiO}_{2} \mathrm{NPs}$ (anatase). The animals were exposed to $\mathrm{TiO}_{2}$ NPs of two different sizes $(25 \mathrm{~nm}$ and $75 \mathrm{~nm}$ ) in the concentration range $10-1000 \mu \mathrm{g} \mathrm{TiO}_{2} / \mathrm{g}$ dry food for 3 to 14 days. No adverse effects, such as mortality, body weight changes or reduced feeding, were observed. In fact, quite the opposite, an enhanced feeding rate, food absorption efficiency and increase in catalase activity were observed. The intensity of these responses appeared to be time- but not dose-dependent. It should also be noted that the concentrations tested in this study were much higher than the predicted concentration $(4.8 \mu \mathrm{g} / \mathrm{g}$ soil) at high emission scenario of nano-sized $\mathrm{TiO}_{2} \cdot{ }^{168}$ Using the same test organism another group ${ }^{169}$ showed that exposure to 
$\mathrm{TiO}_{2}$ NPs induced destabilization of cell membrane in the epithelium of digestive glands isolated from exposed animals. They also showed that this effect can be observed after just 30 minutes of exposure.

$\mathrm{TiO}_{2} \mathrm{NPs}$ appeared to be more toxic to nematode Caenorhabditis elegans than submicron-sized $\mathrm{TiO}_{2} \cdot{ }^{170}$ At a concentration of $1 \mathrm{mg} / \mathrm{l}, 7 \mathrm{~nm}$ particles affected its fertility and survival rate and were more toxic than $20 \mathrm{~nm}$ anatase particles. ${ }^{171}$ Similarly, $\mathrm{Hu}$ et al. ${ }^{172}$ showed that rutile particles $(10-20 \mathrm{~nm})$, at concentrations above $1 \mathrm{~g} / \mathrm{kg}$ soil, can be bio-accumulated in earthworms, where they induce oxidative stress, inhibit the activity of cellulase and induce DNA and mitochondrial damage.

\section{The effects of $\mathrm{TiO}_{2}$ NPs in plants}

In addition to the toxic effects of $\mathrm{TiO}_{2} \mathrm{NPs}$, discussed in previous chapters, these NPs have been also shown to promote photosynthesis and nitrogen metabolism, resulting in the enhanced growth of spinach. ${ }^{173-175}$ It increases the absorption of light and accelerates the transfer and transformation of the light energy. ${ }^{176}$ It was also found that treatment with nano-sized $\mathrm{TiO}_{2}$ significantly increased the level of antioxidant enzymes, and decreased the ROS accumulation and malonyldialdehyde content in spinach chloroplasts under visible and UV irradiation. ${ }^{177} \mathrm{TiO}_{2}$ NPs also increased the superoxide dismutase activity of germinating soybean, enhanced its antioxidant ability, and promoted seed germination and seedling growth. ${ }^{178}$

\section{Potential desirable effects of $\mathrm{TiO}_{2}$ NPs}

The same properties of nano-sized $\mathrm{TiO}_{2}$ that are associated with undesirable, harmful effects can be exploited for certain useful applications. The antimicrobial effect of photo-activated $\mathrm{TiO}_{2} \mathrm{NPs}$ has been known since $1985^{179}$ and since then numerous reports have described its potential antimicrobial activity against numerous microorganisms. ${ }^{180}$ As expected, the antimicrobial effect increases with smaller particle sizes ${ }^{181}$; however, powder agglomeration may obscure this effect. ${ }^{151}$ When submitted to UV-C irradiation, $\mathrm{TiO}_{2}$ depresses the photo-activation and dark repair of DNA in bacteria, which increases the bactericidal efficiency of UV-C irradiation. ${ }^{182}$

$\mathrm{TiO}_{2}$ NPs have potential application in removing or minimizing the effect of the red tides ${ }^{183}$ that are associated with the harmful algae K.brevis that produces neurotoxic brevetoxin (PbTxs). Further, it can be used for disinfecting water, air and surfaces, with possible applications of $\mathrm{TiO}_{2}$ in form of solid films or free particles. Given its use for eradicating toxins, pollutants and spores from water and air, it can be classified as a broad-spectrum oxidizing/cleaning substance. However, an informed balance between the benefits of such a cleaning system and its potential adverse effects needs to be maintained.

NPs are offering new possibilities for in medicine either for diagnostic or therapeutic purposes. For instance recent studies indicate that magnetic NPs may be used in cancer treatment for targeted drug delivery. ${ }^{184}$ Several recent studies indicated that also cultured cancer cells are more sensitive to $\mathrm{TiO}_{2}$ NPs than normal cells.. Photo-activated $\mathrm{TiO}_{2}$ exhibited selective cytotoxicity against highly malignant breast-cancer cells MDA-MB-468, in comparison with non-malignant MCF-7 cells. ${ }^{185}$ Similarly, UV-irradiated Degussa $\mathrm{P} 25 \mathrm{TiO}_{2} \mathrm{NPs}$ reduced viability of sarcoma cells but were not toxic to cultured fibroblasts MCR-5. ${ }^{186}$ In addition, UV-C photo-activated $\mathrm{TiO}_{2}$ particles inhibited aggregation of sarcoma cells with human platelets, thus preventing the formation of metastases. Cai et al. ${ }^{187}$ found that photo-activated $(50 \mu \mathrm{g} / \mathrm{ml})$, but not non-irradiated nano-sized $\mathrm{TiO}_{2}$, was lethal for HeLa cells in vitro and suppressed the growth of HeLa tumours in nude mice. Photo-activated $\mathrm{TiO}_{2}$ also showed antitumour activity in vivo against murine skin tumours. ${ }^{188}$ The potential usefulness of nano-sized $\mathrm{TiO}_{2}$ in cancer cell therapy has also been reported by other research groups. ${ }^{189-192}$ Cytotoxicity against different cancer cell lines appears to depend on the cell type, the particle concentration and the surface chemistry.

The appearance of multidrug-resistant tumour cells is a major obstacle to the success of chemotherapy. Song et al. ${ }^{193}$ reported an enhanced effect of nano-sized $\mathrm{TiO}_{2}$ on drug uptake by drug-resistant leukaemia cells under UV irradiation. Very promising is also the finding that cancer cells can be effectively destroyed by the use of X-ray irradiated nano-sized $\mathrm{TiO}_{2}{ }^{194} \mathrm{~A}$ combination of monoclonal antibody conjugated nano-sized $\mathrm{TiO}_{2}$ with photoinduction $^{195}$ and electroporation ${ }^{196}$ have also been proposed for selective cancer treatment. The monoclonal antibodies would enable selective targeting of cancer cells, photoinduction would trigger local generation of radicals and electroporation would accelerate the delivery of nano-sized $\mathrm{TiO}_{2}$ into the cancer cells. A novel possibility of cancer treatment was recently suggested ${ }^{197}$, in which $\mathrm{TiO}_{2}$ 
NPs and folic acid were coupled and shown to be internalized by HeLa cells via the folate receptor.

\section{Where we are and where to go}

The mechanistic toxicological studies showed that $\mathrm{TiO}_{2}$ NPs induced adverse effects are predominantly mediated by oxidative stress, which may lead to cell damage, genotoxic effects, inflammatory responses and changes in cell signalling. The studies also showed that these effects strongly depend on numerous chemical and physical characteristics of the $\mathrm{TiO}_{2}$ particles: size, crystal structure, specific surface area, particle shape, purity, surface charge, solubility, agglomeration rate, photo-activation, etc. $\mathrm{TiO}_{2}$ particles are without doubt associated with the hazardous properties, and the risk for human health and environment depends on the route and extent of exposure.

Based on the widespread use of creams with SPF based on nano-sized $\mathrm{TiO}_{2}$, human exposure to $\mathrm{TiO}_{2}$ NPs by dermal applications is apparently enormous. In vitro studies with skin models showed that $\mathrm{TiO}_{2}$ NPs are taken up by keratinocytes, fibroblasts, and melanocytes, in which they cause toxic effects that are not different from the effects observed in other cell types. Current experimental evidence indicates that $\mathrm{TiO}_{2} \mathrm{NPs}$ do not penetrate through healthy skin and thus do not reach viable skin cells and distribute to other organs and tissues. However, the data on $\mathrm{TiO}_{2}$ NPs skin penetration during long-term or repeated exposure and in the presence of UV, which is actually characteristic for real life exposure, are insufficient. Therefore, there is no simple answer to the question regarding safety of the use of $\mathrm{TiO}_{2} \mathrm{NPs}$ in sunscreens. The safety of the use of $\mathrm{TiO}_{2}$ in cosmetics is often argumented by the claim, that it has been used for decades without observing any adverse effects on human health. This, however, is not completely true, as no monitoring and post market health surveillance has been conducted, neither for submicronsized nor for nano-sized $\mathrm{TiO}_{2}$ in sunscreens. Such surveillance is currently impossible, since current legislation does not require labelling whether the products contain nano-sized $\mathrm{TiO}_{2}$, which is also incorrect to customers who have no possibility to make a choice whether to use or not the sunscreen containing nano-sized $\mathrm{TiO}_{2}$. In our opinion dermal applications of $\mathrm{TiO}_{2} \mathrm{NPs}$ as sunscreen should be limited until appropriate long-term experimental studies confirm their harmlessness. It is undeniable that long-term sun exposure can induce skin cancer. It is questionable, however, whether people are, by using sunscreens, actually encouraged to expose themselves to the sun instead of avoiding it, and if the benefit provided by $\mathrm{TiO}_{2}$ as a protection from UV compensates for the potential harm.

The available data on absorption, distribution, elimination or any consequent adverse effects after oral exposure to specific $\mathrm{TiO}_{2} \mathrm{NPs}$ are extremely limited. $\mathrm{TiO}_{2} \mathrm{NPs}$ have been shown to be absorbed from gastrointestinal tract and distributed to other organs, however this was observed at extremely high, for human exposure, irrelevant doses. On the other hand, it has been shown that at lower concentrations $\mathrm{TiO}_{2}$ may induce different adverse effects. $\mathrm{TiO}_{2}$ is an approved food additive with the limit set at $1 \%$ by weight of the food; however, neither the size nor the structure is defined. It has been estimated that the average daily exposure to $\mathrm{TiO}_{2}$ from food, medicines and toothpaste is around $5 \mathrm{mg} / \mathrm{in}-$ dividual (i.e., about $0.07 \mathrm{mg} / \mathrm{kg} \mathrm{BW})^{198}$, which is a much lower dose than those that showed adverse effects in experimental animals. Currently there is no data if, and what proportion of $\mathrm{TiO}_{2} \mathrm{NPs}$ is absorbed at doses relevant for human exposure, and how different food matrices affect behaviour and absorption of $\mathrm{TiO}_{2} \mathrm{NPs}$. However, even if very small portion of consumed nano-sized $\mathrm{TiO}_{2}$ is absorbed from gastrointestinal tract and distributed to distant organs, this brings into question accumulation of $\mathrm{TiO}_{2} \mathrm{NPs}$ that may, through a constant lifetime oral exposure, reach concentrations that would trigger adverse effects. Another important question, which should not be neglected is, whether low exposure may trigger symptoms in subjects with an underlying susceptibility. Before in vivo toxicokinetic data for nano-sized $\mathrm{TiO}_{2}$ are available, no conclusion about the risk of nano-sized $\mathrm{TiO}_{2}$ by oral exposure is possible. Therefore, it should be seriously reconsidered if the use of $\mathrm{TiO}_{2} \mathrm{NPs}$ in nutrition and pharmacy just to shade or stabilise the products is justified at all.

Inhalation seems to be the most vulnerable entrance point of the $\mathrm{TiO}_{2} \mathrm{NPs}$ and the toxic effects of inhalation exposure are therefore by far the most studied. Animal studies showed that on inhalation exposure the particles deposit in the lung, where they may cause chronic inflammation and lung-tissue damage, which can lead to lung-tumour development. The important finding is that inhalation exposure to nano-sized $\mathrm{TiO}_{2}$ represents a higher health risk than exposure to submicron-sized $\mathrm{TiO}_{2}$ particles. Experimental data indicate that on inhalation exposure nano-sized $\mathrm{TiO}_{2}$ may translocate to distant organs and tissues, which may be associ- 
ated with systemic effects, such as allergy, asthma and cardiovascular effects, however further studies are needed to confirm these observations and to clarify if they are associated with increased risk for humans. In the scientific community there is still a debate whether the data from in vivo rodent toxicity studies are reliable enough to predict the effects in humans in particular regarding mode of exposure (instillation vs. inhalation exposure) and the differences in susceptibility between different experimental species. Nevertheless, the experimental evidence, although not clearly supported by human epidemiological data, was considered to be sufficient to classify $\mathrm{TiO}_{2}$ (unrespectable to particle size and form) as "possible human carcinogen" upon inhalation exposure by IARC. Recently also NIOSH classified nano-sized, but not submicron-sized $\mathrm{TiO}_{2}$ as occupational carcinogen, and accordingly established different limit values for occupational inhalation exposure for nanosized $\left(0.3 \mathrm{mg} / \mathrm{m}^{3}\right)$ and submicron-sized $\left(2.4 \mathrm{mg} / \mathrm{m}^{3}\right)$ $\mathrm{TiO}_{2}$. At present, through environmental air pollution general population is probably not at risk. However, occupational exposure should be controlled and protective measures applied, not only in $\mathrm{TiO}_{2}$ production industries, but also in certain areas of $\mathrm{TiO}_{2}$ applications; for instance when removing paints or destroying $\mathrm{TiO}_{2}$ containing materials the workers may be exposed to high concentrations of $\mathrm{TiO}_{2}$. Thus, accurate, portable, and cost effective measurement techniques should be developed and applied for effective exposure control and protection.

$\mathrm{TiO}_{2}$ can also be released within the human body as a result of the wear of Ti-based implants. The released particles cause local inflammation, but even more importantly they distribute over the body and can potentially cause systemic effects. Generally the benefit provided by the implant compensates for the potential harm, in particular in the cases where there is no better alternative to the Tibased implants available. However, although there is no direct experimental evidence that released $\mathrm{TiO}_{2}$ can be deposited in the body or can cause systemic effects, it can be postulated from other exposure studies and mechanistic data that at least for individuals with hypersensitivity to titanium such exposure may represent a permanent health threat. Thus, it should be obligatory to test the patients for titanium hypersensitivity prior to implantation of titanium based implants.

Due to the widespread use $\mathrm{TiO}_{2}$ can enter aquatic and terrestrial environment and potentially affect the indigenous organisms. Although data from acute ecotoxicity tests in crustaceans, fish and algae indicate a low toxic potential of $\mathrm{TiO}_{2} \mathrm{NPs}$ for aquatic species, when chronic exposure was applied $\mathrm{TiO}_{2}$ NPs induced a range of sub-lethal adverse effects. In addition it has been shown that nano-sized $\mathrm{TiO}_{2}$ can enter the freshwater food chain, which means that it can be transferred from lower to higher trophic organisms, including humans.

Taken together, the overall exposure of an average individual $\mathrm{TiO}_{2}$ NPs is not known; there are still opened questions regarding toxicokinetics and specific organ toxicity of $\mathrm{TiO}_{2} \mathrm{NPs}$, in particular at oral and dermal exposure, and thus it is impossible to make a reliable quantitative risk assessment. One of the main observations of this review is that, due to the versatility of the $\mathrm{TiO}_{2} \mathrm{NPs}$ in terms of particle size, shape, crystal structure, dispersion in biological surroundings (bioavailability) and UVinduced photocatalytic activity, no single conclusion can be drawn, since different forms of $\mathrm{TiO}_{2}$ may act very differently. Until we know more, in our opinion $\mathrm{TiO}_{2}$ NPs should be used with great care, in particular in food and cosmetics. The least that should be done for the consumer is that a declaration of nano-sized $\mathrm{TiO}_{2}$ in these products is obligatory, so that we will have the choice whether to use it or not.

\section{Acknowledgement}

The study was supported financially by the Slovenian Research Agency within the research programmes "Nanostructured Materials" (P2-0084) and "Ecotoxicology, Toxicological Genomics and Carcinogenesis (P1-0245). We thank Prof. Roger Pain and Assist. Prof. Paul McGuiness for critical reading of the manuscript. Authors would also like to thank Dr. Zoran Samardžija for field-emissiongun scanning electron microscopy observations of the $\mathrm{TiO}_{2}$ powders.

\section{References}

1. Ophus EM, Rode L, Gylseth B, Nicholson DG, Saeed K. Analysis of titanium pigments in human lung tissue. Scand J Work Environ Health 1979; 53: 290-6.

2. Lindenschmidt RC, Driscoll KE, Perkins MA, Higgins JM, Maurer JK, Belfiore KA. The comparison of a fibrogenic and two nonfibrogenic dusts by bronchoalveolar lavage. Toxicol Appl Pharmacol 1990; 102: 268-81.

3. Backus R. Lighting up time for TiO2. Industrial Minerals 2007; 473: 28-39.

4. Robichaud CO, Uyar AE, Darby MR, Zucker LG, Wiesner MR. Estimates of upper bounds and trends in nano-TiO2 production as a basis for exposure assessment. Environ Sci Technol 2009; 43: 4227-33. 
5. Rowe RC, Sheskey PJ, Weller PJ. Handbook of pharmaceutical excipients Fourth ed. London: Pharmaceutical Press, London, United Kingdom, and the American Pharmaceutical Association; 2003.

6. Klaine SJ, Alvarez PJ, Batley GE, Fernandes TF, Handy RD, Lyon DY, et al. Nanomaterials in the environment: behaviour, fate, bioavailability, and effects. Environ Toxicol Chem 2008; 27: 1825-51.

7. Auffan M, Rose J, Bottero JY, Lowry GV, Jolivet JP, Wiesner MR. Towards a definition of inorganic nanoparticles from an environmental, health and safety perspective. Nat Nanotechnol 2009; 4: 634-41.

8. Kosmulski M. The pH-dependent surface charging and points of zero charge V. Update. J Colloid Interface Sci 2011; 353: 1-15.

9. Tang H, Prasad K, Sanjinbs R, Schmid P E, Levy F. Electrical and optical properties of Ti02 anatase thin films. J Appl Phys 2004; 75: 2042-7.

10. Augustynski J. The role of the surface intermediates in the photoelectrochemical behaviour of anatase and rutile TiO2. Electrochimica Acta 1993; 38: $43-6$.

11. Hewitt JP. Titanium dioxide: a different kind of sunshield. Drug Cosmet Ind 1992; 151: 26-32.

12. Fujishima A, Zhang $X$, Tryk DA. TiO2 photocatalysis and related surface phenomena. Surf Sci Rep 2008; 63: 515-82.

13. Xia T, Kovochich M, Brant J, Hotze M, Sempf J, Oberley T, et al. Comparison of the abilities of ambient and manufactured nanoparticles to induce cellular toxicity according to an oxidative stress paradigm. Nano Lett 2006; 68 : 1794-807.

14. Geiser M, Casaulta M, Kupferschmid B, Schulz H, Semmler-Behnke M, Kreyling $\mathrm{W}$. The role of macrophages in the clearance of inhaled ultrafine titanium dioxide particles. Am J Respir Cell Mol Biol 2008; 38: 371-6.

15. Aderem A, Underhill DM. Mechanisms of phagocytosis in macrophages. Annu Rev Immunol 1999; 17: 593-623.

16. Stearns RC, Paulauskis JD, Godleski JJ. Endocytosis of ultrafine particles by A549 cells. Am J Respir Cell Mol Biol 2001; 24: 108-15.

17. Geiser M, Rothen-Rutishauser B, Kapp N, Schurch S, Kreyling W, Schulz $\mathrm{H}$, et al. Ultrafine particles cross cellular membranes by nonphagocytic mechanisms in lungs and in cultured cells. Environ Health Perspect 2005; 113: $1555-60$.

18. Rothen-Rutishauser BM, Schurch S, Haenni B, Kapp N, Gehr P. Interaction of fine particles and nanoparticles with red blood cells visualized with advanced microscopic techniques. Environ Sci Technol 2006; 40: 4353-9.

19. Kocbek P, Teskac K, Kreft ME, Kristl J. Toxicological aspects of long-term treatment of keratinocytes with $\mathrm{ZnO}$ and $\mathrm{TiO} 2$ nanoparticles. Small 2010; 6: 1908-17.

20. Xia T, Kovochich M, Liong M, Madler L, Gilbert B, Shi HB, et al. Comparison of the mechanism of toxicity of zinc oxide and cerium oxide nanoparticles based on dissolution and oxidative stress properties. Acs Nano 2008; 2: 2121-34.

21. Donaldson K, Stone V, Clouter A, Renwick L, MacNee W. Ultrafine particles. Occup Environ Med 2001; 58: 211-6.

22. Nel A, Xia T, Madler L, Li N. Toxic potential of materials at the nanolevel. Science 2006; 311: 622-7.

23. Dunford R, Salinaro A, Cai LZ, Serpone N, Horikoshi S, Hidaka H, et al. Chemical oxidation and DNA damage catalysed by inorganic sunscreen ingredients. Febs Lett 1997; 418: 87-90.

24. Gurr JR, Wang ASS, Chen CH, Jan KY. Ultrafine titanium dioxide particles in the absence of photoactivation can induce oxidative damage to human bronchial epithelial cells. Toxicology 2005; 213: 66-73.

25. Long TC, Tajuba J, Sama P, Saleh N, Swartz C, Parker J, et al. Nanosize titanium dioxide stimulates reactive oxygen species in brain microglia and damages neurons in vitro. Environ Health Persp 2007; 115: 1631-7.

26. Lu N, Zhu Z, Zhao X, Tao R, Yang X, Gao Z. Nano titanium dioxide photocatalytic protein tyrosine nitration: a potential hazard of $\mathrm{TiO} 2$ on skin. Biochem Biophys Res Commun 2008; 370: 675-80.

27. Park EJ, Yi J, Chung YH, Ryu DY, Choi J, Park K. Oxidative stress and apoptosis induced by titanium dioxide nanoparticles in cultured BEAS-2B cells. Toxicol Lett 2008; 180: 222-9.
28. Sayes CM, Wahi R, Kurian PA, Liu Y, West JL, Ausman KD, et al. Correlating nanoscale titania structure with toxicity: a cytotoxicity and inflammatory response study with human dermal fibroblasts and human lung epithelial cells. Toxicol Sci 2006; 92: 174-85.

29. Wang JX, Chen CY, Liu Y, Jiao F, Li W, Lao F, et al. Potential neurological lesion after nasal instillation of $\mathrm{TiO} 2$ nanoparticles in the anatase and rutile crystal phases. Toxicol Lett 2008; 183: 72-80.

30. Uchino T, Tokunaga $H$, Ando M, Utsumi H. Quantitative determination of $\mathrm{OH}$ radical generation and its cytotoxicity induced by $\mathrm{TiO}$-UVA treatment. Toxicol in Vitro 2002; 16: 629-35.

31. Dodd NJ, Jha AN. Titanium dioxide induced cell damage: a proposed role of the carboxyl radical. Mutat Res 2009; 660: 79-82.

32. Petković J, Žegura B, Stevanović M, Drnovšek N, Uskoković D, Novak S et al. DNA damage and alterations in expression of DNA damage responsive genes induced by $\mathrm{TiO} 2$ nanoparticles in human hepatoma HepG2 cells. Nanotoxicology 2011; 5: 341-53.

33. Petković J, Küzma T, Rade K, Novak S, Filipič M. Pre-irradiation of anatase $\mathrm{TiO} 2$ particles with UV enhances their cytotoxic and genotoxic potential in human hepatoma HepG2 cells. J Hazard Mater 2011; doi: 10.1016/j. jhazmat.2011.09.004.

34. Barthel A, Klotz LO. Phosphoinositide 3-kinase signaling in the cellular response to oxidative stress. Biol Chem 2005; 386: 207-16.

35. Kang JL, Moon C, Lee HS, Lee HW, Park EM, Kim HS, et al. Comparison of the biological activity between ultrafine and fine titanium dioxide particles in RAW 264.7 cells associated with oxidative stress. J Toxicol Environ Health, Part A 2008; 71: 478-85.

36. Rahman Q, Lohani M, Dopp E, Pemsel H, Jonas L, Weiss DG, et al. Evidence that ultrafine titanium dioxide induces micronuclei and apoptosis in Syrian hamster embryo fibroblasts. Environ Health Persp 2002; 110: 797-800.

37. Wang JJ, Sanderson BJS, Wang H. Cyto- and genotoxicity of ultrafine $\mathrm{TiO} 2$ particles in cultured human lymphoblastoid cells. Mutat Res-Gen Tox En 2007; 628: 99-106.

38. Xu A, Chai YF, Nohmi T, Hei TK. Genotoxic responses to titanium dioxide nanoparticles and fullerene in gpt delta transgenic MEF cells. Part Fibre Toxicol 2009; 6: 3.

39. Zhu RR, Wang SL, Chao J, Shi DL, Zhang R, Sun XY, et al. Bio-effects of Nano$\mathrm{TiO} 2$ on DNA and cellular ultrastructure with different polymorph and size. Mat Sci Eng C-Bio S 2009; 29: 691-6.

40. Kang SJ, Kim BM, Lee YJ, Chung HW. Titanium dioxide nanoparticles trigger p53-mediated damage response in peripheral blood lymphocytes. Environ Mol Mutagen 2008; 49: 399-405.

41. Warheit DB, Hoke RA, Finlay C, Donner EM, Reed KL, Sayes CM. Development of a base set of toxicity tests using ultrafine $\mathrm{TiO} 2$ particles as a component of nanoparticle risk management. Toxicol Lett 2007; 171: 99-110.

42. Theogaraj E, Riley S, Hughes L, Maier M, Kirkland D. An investigation of the photo-clastogenic potential of ultrafine titanium dioxide particles. Mutat Res-Gen Tox En 2007; 634: 205-19.

43. Driscoll KE, Deyo LC, Carter JM, Howard BW, Hassenbein DG, Bertram TA Effects of particle exposure and particle-elicited inflammatory cells on mutation in rat alveolar epithelial cells. Carcinogenesis 1997; 18: 423-30.

44. Trouiller B, Reliene R, Westbrook A, Solaimani P, Schiestl RH. Titanium dioxide nanoparticles induce DNA damage and genetic instability in vivo in mice. Cancer Res 2009; 69: 8784-9.

45. Li N, Ma LL, Wang J, Zheng L, Liu J, Duan YM, et al. Interaction between nano-anatase TiO2 and liver DNA from mice in vivo. Nanoscale Res Lett 2010; 51: 108-15.

46. Vamanu Cl, Cimpan MR, Hol PJ, Sornes S, Lie SA, Gjerdet NR. Induction of cell death by $\mathrm{TiO} 2$ nanoparticles: Studies on a human monoblastoid cell line. Toxicol in Vitro 2008; 22: 1689-96.

47. Palomaki J, Karisola P, Pylkkanen L, Savolainen K, Alenius H. Engineered nanomaterials cause cytotoxicity and activation on mouse antigen presenting cells. Toxicology 2010; 267: 125-31.

48. Larsen ST, Roursgaard M, Jensen KA, Nielsen GD. Nano titanium dioxide particles promote allergic sensitization and lung inflammation in mice. Basic Clin Pharmacol Toxicol 2010; 106: 114-7. 
49. de Haar C, Hassing I, Bol M, Bleumink R, Pieters R. Ultrafine but not fine particulate matter causes airway inflammation and allergic airway sensitization to co-administered antigen in mice. Clin Exp Allergy 2006; 36: 1469-79.

50. Moon EY, Yi GH, Kang JS, Lim JS, Kim HM, Pyo S. An increase in mouse tumor growth by an in vivo immunomodulating effect of titanium dioxide nanoparticles. J Immunotoxicol 2011; 81: 56-67.

51. Borm PJ, Robbins D, Haubold S, Kuhlbusch T, Fissan H, Donaldson K, et al. The potential risks of nanomaterials: a review carried out for ECETOC. Part Fibre Toxicol 2006; 3: 11.

52. Peters A, Veronesi B, Calderon-Garciduenas L, Gehr P, Chen LC, Geiser M, et al. Translocation and potential neurological effects of fine and ultrafine particles a critical update. Part Fibre Toxicol 2006; 3: 13.

53. Long TC, Saleh N, Tilton RD, Lowry GV, Veronesi B. Titanium dioxide (P25) produces reactive oxygen species in immortalized brain microglia (BV2): Implications for nanoparticle neurotoxicity. Environ Sci Technol 2006; 40: 4346-52.

54. Liu SC, Xu ப, Zhang T, Ren GG, Yang Z. Oxidative stress and apoptosis induced by nanosized titanium dioxide in PC12 cells. Toxicology 2010; 267: 172-7.

55. Liu XY, Ren XF, Deng XY, Huo YA, Xie J, Huang H, et al. A protein interaction network for the analysis of the neuronal differentiation of neural stem cells in response to titanium dioxide nanoparticles. Biomaterials 2010; 31: 3063-70.

56. Scuri M, Chen BT, Castranova V, Reynolds JS, Johnson VJ, Samsell L, et al. Effects of titanium dioxide nanoparticle exposure on neuroimmune responses in rat airways. J Toxicol Environ Health, Part A 2010; 73: 1353-69.

57. Nohynek GJ, Schaefer H. Benefit and risk of organic ultraviolet filters. Regu Toxicol Pharmacol 2001; 333: 285-99.

58. FDA. Sunscreen drug products for over-the-counter human use, Final Monograph, Federal Register 64 27666, US Rockville, MD; 2000.

59. Newman MD, Stotland M, Ellis JI. The safety of nanosized particles in titanium dioxide- and zinc oxide-based sunscreens. J Am Acad Dermatol 2009; 61: 685-92.

60. Breggin L, Falkner R, Jaspers N, Pendergrass J, Porter R. Securing the promise of nanotechnologies towards transatlantic regulatory cooperation. London: Affairs Rlol; 2009.

61. Serpone N, Dondi D, Albini A. Inorganic and organic UV filters: Their role and efficacy in sunscreens and suncare products. Inorg Chim Acta 2007; 360: 794-802.

62. Salvador A, Chisvert A. Sunscreen analysis - A critical survey on UV filters determination. Anal Chim Acta 2005; 537: 1-14.

63. Nohynek GJ, Antignac E, Re T, Toutain H. Safety assessment of personal care products/cosmetics and their ingredients. Toxicol Appl Pharmacol 2010; 243: 239-59.

64. Nohynek GJ, Lademann J, Ribaud C, Roberts MS. Grey goo on the skin? Nanotechnology, cosmetic and sunscreen safety. Crit Rev Toxicol 2007; 373 251-77.

65. Salinaro A, Emeline AV, Zhao J., Hidaka. H., Ryabchuk V, Serpone KN Terminology, relative photonic efficiencies and quantum yields in heterogeneous photocatalysis. Part II: Experimental determination of quantum yields (Technical Report). Pure Appl Chem 1999; 71: 321-6.

66. Serpone N, Salinaro A, Hidaka H, Horikoshi S, Knowland J, Dunford R. Sola engineering. In: Morehouse JM, Hogan RE (eds). New York: ASME; 1998.

67. Jaroenworaluck A, Sunsaneeyametha W, Kosachan N, Stevens R. Characteristics of silica-coated TiO2 and its UV absorption for sunscreen cosmetic applications. Surf Interface Anal 2006; 38: 473-7.

68. Labiele J, Feng J, Botta C, Borschneck D, Sammut M, Cabie M, et al. Agging of $\mathrm{TiO} 2$ nanocomposites used in sunscreens. Dispersion and fate of the degradation products in aqueous environment. Environ Pollut 2010; 158 . $1-8$

69. Mills A, Le Hunte S. An overview of semiconductor photocatalysis. $J$ Photoch Photobio A 1997; 108: 1-35.
70. Wakefield G, Lipscomb S, Holland E, Knowland J. The effects of manganese doping on UVA absorption and free radical generation of micronised titanium dioxide and its consequences for the photostability of UVA absorbing organic sunscreen components. Photochem Photobiol Sci 2004; 37: 64852.

71. Pan Z, Lee W, Slutsky L, Clark RA, Pernodet N, Rafailovich MH. Adverse effects of titanium dioxide nanoparticles on human dermal fibroblasts and how to protect cells. Small 2009; 54: 511-20.

72. Kiss B, Biro T, Czifra G, Toth BI, Kertesz Z, Szikszai Z, et al. Investigation of micronized titanium dioxide penetration in human skin xenografts and its effect on cellular functions of human skin-derived cells. Exp Dermatol 2008; 17: 659-67.

73. Jin CY, Zhu BS, Wang XF, Lu QH. Cytotoxicity of titanium dioxide nanoparticles in mouse fibroblast cells. Chem Res Toxicol 2008; 219: 1871-7.

74. Yanagisawa R, Takano H, Inoue K, Koike E, Kamachi T, Sadakane K, et al. Titanium Dioxide Nanoparticles Aggravate Atopic Dermatitis-Like Skin Lesions in NC/Nga Mice. Exp Biol Med 2009; 234: 314-22.

75. Hoet PH, Bruske-Hohlfeld I, Salata OV. Nanoparticles - known and unknown health risks. J Nanobiotechnology 2004; 21: 12.

76. Tyner KM, Wokovich AM, Godar DE, Doub WH, Sadrieh N. The state of nano-sized titanium dioxide (TiO2) may affect sunscreen performance. Int J Cosmetic Sci 2010; 33: 234-44.

77. Lademann J, Weigmann H, Rickmeyer C, Barthelmes $H$, Schaefer $H$, Mueller $\mathrm{G}$, et al. Penetration of titanium dioxide microparticles in a sunscreen formulation into the horny layer and the follicular orifice. Skin Pharmacol Appl Skin Physiol 1999; 12: 247-56.

78. Pflucker F, Wendel V, Hohenberg H, Gartner E, Will T, Pfeiffer S, et al. The human stratum corneum layer: an effective barrier against dermal uptake of different forms of topically applied micronised titanium dioxide. Skin Pharmacol Appl Skin Physiol 2001; 14: 92-7.

79. Schulz J, Hohenberg H, Pflucker F, Gartner E, Will T, Pfeiffer S, et al. Distribution of sunscreens on skin. Adv Drug Deliv Rev 2002; 54: S157-63.

80. Schilling K, Bradford B, Castelli D, Dufour E, Nash JF, Pape W, et al. Human safety review of "nano" titanium dioxide and zinc oxide. Photochem Photobiol Sci 2010; 9: 495-509.

81. Senzui M, Tamura T, Miura K, Ikarashi $Y$, Watanabe $Y$, Fujii M. Study on penetration of titanium dioxide (TiO2) nanoparticles into intact and damaged skin in vitro. J Toxicol Sci 2010; 35: 107-13.

82. Tan MH, Commens CA, Burnett L, Snitch PJ. A pilot study on the percutaneous absorption of microfine titanium dioxide from sunscreens. Australas Dermatol 1996; 37: 185-7.

83. Wu J, Liu W, Xue C, Zhou S, Lan F, Bi L, et al. Toxicity and penetration of TiO2 nanoparticles in hairless mice and porcine skin after subchronic derma exposure. Toxicol Letters 2009; 191: 1-8.

84. Sadrieh N, Wokovich AM, Gopee NV, Zheng JW, Haines D, Parmiter D, et al. Lack of Significant Dermal Penetration of Titanium Dioxide from Sunscreen Formulations Containing Nano- and Submicron-Size TiO(2) Particles. Toxicol Sci 2010; 115: 156-66.

85. Mosteller RD. Simplified calculation of body-surface area. $N$ Engl J Med 1987; 317: 1098

86. FDA [Internet]. Food and drugs chapter I, Listing of color additives exempt from certification. Federal Register 21CFR73, US Rockville, MD; 2010; [cited 2011 October 14]. Available from: http://www.accessdata.fda.gov/scripts/ cdrh/cfdocs/cfcfr/CFRSearch.cfm?CFRPart=73\&showFR=1.

87. Kumagai K. Uber den Resorptionvergang der corpuscularen Bestandteile im Darm. 192: 429-31.

88. Jani PU, McCarthy DE, Florence AT. Titanium dioxide (rutile) particle uptake from the rat GI tract and translocation to systemic organs after oral administration. Int J Pharm 1994; 105: 157-68.

89. Wang JX, Zhou GQ, Chen CY, Yu HW, Wang TC, Ma YM, et al. Acute toxicity and biodistribution of different sized titanium dioxide particles in mice after oral administration. Toxicol Lett 2007; 168: 176-85.

90. Duan Y, Liu J, Ma L, Li N, Liu H, Wang J, et al. Toxicological characteristics of nanoparticulate anatase titanium dioxide in mice. Biomaterials 2010; 31: 894-9. 
91. Powell JJ, Harvey RSJ, Ashwood P, Wolstencroft R, Gershwin ME, Thompson $\mathrm{RPH}$. Immune potentiation of ultrafine dietary particles in normal subjects and patients with inflammatory bowel disease. J Autoimmun 2000; 14: 99-105.

92. National Cancer Institute. Bioassay of titanium dioxide for possible carcinogenicity. Washington, DC: U.S. Department of Health, Education, and Welfare, Public Health Service, National Institutes of Health; 1979.

93. Bernard BK, Osheroff MR, Hofmann A, Mennear JH. Toxicology and carcinogenesis studies of dietary titanium dioxide-coated mica in male and female Fischer 344 rats. J Toxicol Env Health 1990; 29: 417-29.

94. Okazaki Y, Gotoh E. Comparison of metal release from various metallic biomaterials in vitro. Biomaterials 2005; 26: 11-21.

95. Hext PM, Tomenson JA, Thompson P. Titanium dioxide: inhalation toxicology and epidemiology. Ann Occup Hyg 2005; 49: 461-72.

96. Fryzek JP, Chadda B, Marano D, White K, Schweitzer S, McLaughlin JK, et al. A cohort mortality study among titanium dioxide manufacturing workers in the United States. J Occup Environ Med 2003; 45: 400-9.

97. Boffetta P, Soutar A, Cherrie JW, Granath F, Andersen A, Anttila A, et al. Mortality among workers employed in the titanium dioxide production industry in Europe. Cancer Causes Control 2004; 157: 697-706.

98. NIOSH. Occupational Exposure to Titanium Dioxid. Department Of Health And Human Services, Centers for Disease Control and Prevention, National Institute for Occupational Safety and Health 2011.

99. Peters A, Dockery DW, Muller JE, Mittleman MA. Increased particulate air pollution and the triggering of myocardial infarction. Circulation 2001; 103: 2810-5.

100. Peters A, Doring A, Wichmann HE, Koenig W. Increased plasma viscosity during an air pollution episode: a link to mortality? Lancet 1997; 349: 15827.

101. McGuinnes C, Duffin R, Brown S, Mills NL, Megson IL, MacNee W, et al. Surface derivatization state of polystyrene latex nanoparticles determines both their potency and their mechanism of causing human platelet aggregation in vitro. Toxicol Sci 2011; 119: 359-68.

102. Donaldson K, Stone V, Seaton A, MacNee W. Ambient particle inhalation and the cardiovascular system: Potential mechanisms. Environ Health Perspect 2001; 109: 523-27.

103. Ferin J, Oberdorster G, Penney DP. Pulmonary retention of ultrafine and fine particles in rats. Am J Respir Cell Mol Biol 1992; 65: 535-42.

104. Oberdörster G, Ferin J, Lehnert BE. Correlation between particle-size, in vivo particle persistence, and lung injury. Environ Health Perspect 1994 102: 173-9.

105. Renwick LC, Donaldson K, Clouter A. Impairment of alveolar macrophage phagocytosis by ultrafine particles. Toxicol Appl Pharmacol 2001; 172: 11927.

106. van Ravenzwaay B, Landsiedel R, Fabian E, Burkhardt S, Strauss V, Ma-Hock L. Comparing fate and effects of three particles of different surface properties: nano-TiO2, pigmentary TiO2 and quartz. Toxicol Lett 2009; 186: 152-9.

107. Kapp N, Studer D, Gehr P, Geiser M. Electron energy-loss spectroscopy as a tool for elemental analysis in biological specimens. Methods Mol Biol 2007; 369: 431-47.

108. Nemmar A, Vanbilloen H, Hoylaerts MF, Hoet PH, Verbruggen A, Nemery B. Passage of intratracheally instilled ultrafine particles from the lung into the systemic circulation in hamster. Am J Respir Crit Care Med 2001; 164: 1665-8.

109. Nurkiewicz TR, Porter DW, Hubbs AF, Cumpston JL, Chen BT, Frazer DG, et al. Nanoparticle inhalation augments particle-dependent systemic microvascular dysfunction. Part Fibre Toxicol 2008; 5:1.

110. Kim HW, Ahn EK, Jee BK, Yoon HK, Lee KH, Lim Y. Nanoparticulate-induced toxicity and related mechanism in vitro and in vivo. J Nanopart Res 2009; 111: 55-65.

111. Oberdorster G. Pulmonary effects of inhaled ultrafine particles. Int Arch Occup Environ Health 2001; 74: 1-8.

112. Warheit DB, Webb TR, Sayes CM, Colvin VL, Reed KL. Pulmonary instillation studies with nanoscale $\mathrm{TiO} 2$ rods and dots in rats: Toxicity is not dependent upon particle size and surface area. Toxicol Sci 2006; 91: 227-36.
113. Rehn B, Seiler F, Rehn S, Bruch J, Maier M. Investigations on the inflammatory and genotoxic lung effects of two types of titanium dioxide: untreated and surface treated. Toxicol Appl Pharmacol 2003; 189: 84-95.

114. Grassian VH, O'Shaughnessy PT, Adamcakova-Dodd A, Pettibone JM, Thorne PS. Inhalation exposure study of titanium dioxide nanoparticles with a primary particle size of 2 to $5 \mathrm{~nm}$. Environ Health Perspect 2007; 115: 397-402.

115. Warheit DB, Webb TR, Reed KL, Frerichs S, Sayes CM. Pulmonary toxicity study in rats with three forms of ultrafine-TiO2 particles: Differential responses related to surface properties. Toxicology 2007; 230: 90-104.

116. Roursgaard M, Jensen KA, Poulsen SS, Jensen NEV, Poulsen LK, Hammer M, et al. Acute and subchronic airway inflammation after intratracheal instillation of quartz and titanium dioxide agglomerates in mice. Scientific World Journal 2011; 11: 801-25.

117. Chen HW, Su SF, Chien CT, Lin WH, Yu SL, Chou CC, et al. Titanium dioxide nanoparticles induce emphysema-like lung injury in mice. FASEB J 2006; 20: $2393-5$.

118. Park EJ, Yoon J, Choi K, Yi J, Park K. Induction of chronic inflammation in mice treated with titanium dioxide nanoparticles by intratracheal instillation. Toxicology 2009; 260: 37-46.

119. Lee KP, Trochimowicz HJ, Reinhardt CF. Pulmonary Response of Rats Exposed to Titanium-Dioxide (TiO2) by Inhalation for 2 Years. Toxicol App Pharmacol 1985; 79: 179-92.

120. Borm PJA, Hohr D, Steinfartz Y, Zeittrager I, Albrecht C. Chronic inflammation and tumor formation in rats after intratracheal instillation of high doses of coal dusts, titanium dioxides, and quartz. Inhal Toxicol 2000; 12: 225-31.

121. Heinrich U, Fuhst R, Rittinghausen S, Creutzenberg O, Bellmann B, Koch W, et al. Chronic inhalation exposure of Wistar rats and 2 different strains of mice to diesel-engine exhaust, carbon-black, and titanium-dioxide. Inhal Toxicol 1995; 74: 533-56.

122. Muhle H, Bellmann B, Creutzenberg O, Koch W, Dasenbrock C, Ernst $\mathrm{H}$, et al. Pulmonary response to toner, $\mathrm{TiO} 2$ and crystalline silica upon chronic inhalation exposure in Syrian golden hamsters. Inhal Toxicol 1998; 10: 699729 .

123. Bermudez E, Mangum JB, Asgharian B, Wong BA, Reverdy EE, Janszen DB, et al. Long-term pulmonary responses of three laboratory rodent species to subchronic inhalation of pigmentary titanium dioxide particles. Toxicol Sci 2002; 70: 86-97.

124. Bermudez E, Mangum JB, Wong BA, Asgharian B, Hext PM, Warheit DB, et al. Pulmonary responses of mice, rats, and hamsters to subchronic inhalation of ultrafine titanium dioxide particles. Toxicol Sci 2004; 77: 347-57.

125. Hsieh TH, Yu CP. Two-phase pulmonary clearance of insoluble particles in mammalian species. Inhal Toxicol 1998; 102: 121-30.

126. Wang JX, Liu Y, Jiao F, Lao F, Li W, Gu YQ, et al. Time-dependent translocation and potential impairment on central nervous system by intranasally instilled TiO2 nanoparticles. Toxicology 2008; 254: 82-90.

127. Yamadori I, Ohsumi S, Taguchi K. Titanium dioxide deposition and adenocarcinoma of the lung. Acta Pathol Jpn 1986; 36: 783-90.

128. Chen JL, Fayerweather WE. Epidemiologic-study of workers exposed to titanium-dioxide. J Occup Environ Med 1988; 30: 937-42.

129. Ramanakumar AV, Parent ME, Latreille B, Siemiatycki J. Risk of lung cancer following exposure to carbon black, titanium dioxide and talc: results from two case-control studies in Montreal. Int J Cancer 2008; 122: 183-9.

130. Boffetta P, Soutar A, Cherrie JW, Granath F, Andersen A, Anttila A, et al. Mortality among workers employed in the titanium dioxide production industry in Europe. Cancer Causes Control 2004; 15: 697-706.

131. IARC. Carbon black, titanium dioxide, and talc. IARC monographs on the evaluation of carcinogenic risks to humans, vol. 93. International Agency for Research on Cancer: Lyon, France, 2006.

132. Baan R, Straif K, Grosse Y, Secretan B, El Ghissassi F, Cogliano V. Carcinogenicity of carbon black, titanium dioxide, and talc. Lancet Oncol 2006; 74: 295-6.

133. Cadosch D, Chan E, Gautschi OP, Filgueira L. Metal is not inert: Role of metal ions released by biocorrosion in aseptic loosening-Current concepts. J Biomed Mater Res A 2009; 91: 1252-62. 
134. Sargeant A, Goswami T. Hip implants - Paper VI - Ion concentrations. Mater Design 2007; 28: 155-71.

135. Valentine-Thon E, Schiwara HW. Validity of MELISA (R) for metal sensitivity testing. Neuroendocrinol Lett 2003; 241: 57-64.

136. Hallab N, Merritt K, Jacobs JJ. Metal sensitivity in patients with orthopaedic implants. J Bone Joint Surg Am 2001; 83: 428-36.

137. Wang JX, Fan YB, Gao Y, Hu QH, Wang TC. TiO2 nanoparticles translocation and potential toxicological effect in rats after intraarticular injection. Biomaterials 2009; 30: 4590-600.

138. Urban RM, Jacobs JJ, Tomlinson MJ, Gavrilovic J, Black J, Peoc'h M. Dissemination of wear particles to the liver, spleen, and abdominal lymph nodes of patients with hip or knee replacement. J Bone Joint Surg Am 2000; 82: 457-76.

139. Margevicius KJ, Bauer TW, McMahon JT, Brown SA, Merritt K. Isolation and characterization of debris in membranes around total joint prostheses. $J$ Bone Joint Surg Am 1994; 76: 1664-75

140. Agins HJ, Alcock NW, Bansal M, Salvati EA, Wilson PD, Pellicci PM, et al. Metallic wear in failed titanium-alloy total hip replacements. A histological and quantitative analysis. J Bone Joint Surg Am 1988; 70: 347-56.

141. Giavaresi G, Ambrosio L, Battiston GA, Casellato U, Gerbasi R, Finia M, et al. Histomorphometric, ultrastructural and microhardness evaluation of the osseointegration of a nanostructured titanium oxide coating by metalorganic chemical vapour deposition: an in vivo study. Biomaterials 2004; 25: 5583-91.

142. Cui C, Liu H, Li Y, Sun J, Wang R, Liu S, et al. Fabrication and biocompatibility of nano-TiO2/titanium alloys biomaterials. Mater Lett 2005; 59: 3144-48.

143. Drnovsek N, Daneu N, Recnik A, Mazaj M, Kovac J, Novak S. Hydrothermal synthesis of a nanocrystalline anatase layer on Ti6A4V implants. Surf Coat Tech 2009; 203: 1462-68.

144. Tedetti M, Sempere R. Penetration of ultraviolet radiation in the marine environment. A review. Photochem Photobiol 2006; 82: 389-97.

145. Aruoja V, Dubourguier H-C, Kasemets K, Kahru A. Toxicity of nanoparticles of $\mathrm{CuO}, \mathrm{ZnO}$ and $\mathrm{TiO} 2$ to microalgae Pseudokirchneriella subcapitata. Sci Total Environ 2009; 407: 1461-68.

146. Hund-Rinke K, Simon M. Ecotoxic effect of photocatalytic active nanoparticles (TiO2) on algae and daphnids. Environ Sci Pollut Res Int 2006; 134: 225-32.

147. Hartmann NB, Von der Kammer F, Hofmann T, Baalousha M, Ottofuelling $\mathrm{S}$, Baun A. Algal testing of titanium dioxide nanoparticles--Testing considerations, inhibitory effects and modification of cadmium bioavailability. Toxicology 2010; 269: 190-7.

148. Kim S-C, Lee D-K. Preparation of TiO2-coated hollow glass beads and their application to the control of algal growth in eutrophic water. Microchem J 2005; 80: 227-32.

149. Hong J, Ma H, Otaki M. Controlling algal growth in photo-dependent decolorant sludge by photocatalysis. J Biosci Bioeng 2005; 99: 592-7.

150. Velzeboer I, Hendriks AJ, Ragas AMJ, Van de Meent D. Aquatic ecotoxicity tests of some nanomaterials. Environ Toxicol Chem 2008; 27: 1942-47.

151. Adams LK, Lyon DY, Alvarez PJ. Comparative eco-toxicity of nanoscale TiO2, SiO2, and ZnO water suspensions. Water Res 2006; 40: 3527-32.

152. Zhu X, Chang Y, Chen Y. Toxicity and bioaccumulation of TiO2 nanoparticle aggregates in Daphnia magna. Chemosphere 2010; 78: 209-15.

153. Wiench K, Wohlleben W, Hisgen V, Radke K, Salinas E, Zok S, et al. Acute and chronic effects of nano- and non-nano-scale $\mathrm{TiO}(2)$ and $\mathrm{ZnO}$ particles on mobility and reproduction of the freshwater invertebrate Daphnia magna. Chemosphere 2009; 76: 1356-65.

154. Kim KT, Klaine SJ, Cho J, Kim SH, Kim SD. Oxidative stress responses of Daphnia magna exposed to $\mathrm{TiO}(2)$ nanoparticles according to size fraction. Sci Total Environ; 408: 2268-72.

155. Lee S-W, Kim S-M, Choi J. Genotoxicity and ecotoxicity assays using the freshwater crustacean Daphnia magna and the larva of the aquatic midge Chironomus riparius to screen the ecological risks of nanoparticle exposure. Environ Toxicol Phar 2009; 281: 86-91.
156. Zhu X, Zhu L, Duan Z, Qi R, Li Y, Lang Y. Comparative toxicity of several metal oxide nanoparticle aqueous suspensions to Zebrafish (Danio rerio) early developmental stage. J Environ Sci Health A Tox Hazard Subst Environ Eng 2008; 433: 278-84.

157. Federici G, Shaw BJ, Handy RD. Toxicity of titanium dioxide nanoparticles to rainbow trout (Oncorhynchus mykiss): Gill injury, oxidative stress, and other physiological effects. Aquat Toxicol 2007; 844: 415-30.

158. Scown TM, van Aerle R, Johnston BD, Cumberland S, Lead JR, Owen R, et al. High Doses of Intravenously Administered Titanium Dioxide Nanoparticles Accumulate in the Kidneys of Rainbow Trout but with no Observable Impairment of Renal Function. Toxicol Sci 2009; 109: 372-80.

159. Linhua $\mathrm{H}$, Zhenyu W, Baoshan X. Effect of sub-acute exposure to TiO2 nanoparticles on oxidative stress and histpathological changes in Juvenile Carp (Cyprinus carpio). J Environ Sci 2009; 21: 1459-66.

160. Galloway T, Lewis C, Dolciotti I, Johnston BD, Moger J, Regoli F. Sublethal toxicity of nano-titanium dioxide and carbon nanotubes in a sediment dwelling marine polychaete. Environ Pollut 2010; 158: 1748-55.

161. Zhu X, Wang J, Zhang X, Chang Y, Chen Y. Trophic transfer of TiO(2) nanoparticles from Daphnia to zebrafish in a simplified freshwater food chain. Chemosphere 2010; 79: 928-33.

162. Zhang XZ, Sun HW, Zhang ZY, Niu Q, Chen YS, Crittenden JC. Enhanced bioaccumulation of cadmium incarpinthepresence of titanium dioxidenanoparticles. Chemosphere 2007; 67: 160-66.

163. Sun HW, Zhang XZ, Niu Q, Chen YS, Crittenden JC. Enhanced accumulation of arsenate in carp in the presence of titanium dioxide nanoparticles. Water Air Soil Pollut 2007; 178: 245-54.

164. Canesi L, Ciacci C, Vallotto D, Gallo G, Marcomini A, Pojana G. In vitro effects of suspensions of selected nanoparticles (C60 fullerene, $\mathrm{TiO} 2, \mathrm{SiO} 2$ ) on Mytilus hemocytes. Aquat Toxicol 2010; 96: 151-8.

165. Vevers WF, Jha AN. Genotoxic and cytotoxic potential of titanium dioxide (TiO2) nanoparticles on fish cells in vitro. Ecotoxicology 2008; 175: 410-20.

166. Reeves JF, Davies SJ, Dodd NJF, Jha AN. Hydroxyl radicals $(\mathrm{OH})$ are associated with titanium dioxide(TiO2)nanoparticle-inducedcytotoxicityandoxidative DNA damage in fish cells. Mutat Res-Fund Mol M 2008; 640: 113-22.

167. Drobne D, Jemec A, Pipan Tkalec Z. In vivo screening to determine hazards of nanoparticles: nanosized TiO2. Environ Pollut 2009; 157: 1157-64.

168. Mueller NC, Nowack B. Exposure modeling of engineered nanoparticles in the environment. Environ Sci Technol 2008; 421: 4447-53.

169. Valant J, Drobne D, Sepcic K, Jemec A, Kogej K, Kostanjsek R. Hazardous potential of manufactured nanoparticles identified by in vivo assay. $J$ Hazard Mater 2009; 171: 160-5.

170. Wang H, Wick RL, Xing B. Toxicity of nanoparticulate and bulk $\mathrm{ZnO}, \mathrm{Al} 2 \mathrm{O} 3$ and $\mathrm{TiO} 2$ to the nematode Caenorhabditis elegans. Environ Pollut 2009; 157: $1171-7$

171. Roh J-Y, Park Y-K, Park K, Choi J. Ecotoxicological investigation of $\mathrm{CeO} 2$ and $\mathrm{TiO} 2$ nanoparticles on the soil nematode Caenorhabditis elegans using gene expression, growth, fertility, and survival as endpoints. Environ Toxicol Phar 2010; 29: 167-72.

172. Hu CW, Li M, Cui YB, Li DS, Chen J, Yang LY. Toxicological effects of TiO2 and $\mathrm{ZnO}$ nanoparticles in soil on earthworm Eisenia fetida. Soil Biol Biochem 2010; 42: 586-91.

173. Yang F, Hong F, You W, Liu C, Gao F, Wu C, et al. Influence of nano-anatase TiO\&lt;sub\&gt;2\&lt;/sub\&gt; on the nitrogen metabolism of growing spinach. Biol Trace Elem Res 2006; 110: 179-90.

174. Gao F, Hong F, Liu C, Zheng L, Su M, Wu X, et al. Mechanism of nanoanatase TiO\&lt;sub\&gt;2\&lt;/sub\&gt; on promoting photosynthetic carbon reaction of spinach. Biol Trace Elem Res 2006; 111: 239-53.

175. Gao F, Liu C, Qu C, Zheng L, Yang F, Su M, et al. Was improvement of spinach growth by nano-TiO\&lt;sub\&gt;2\&lt;/sub\&gt; treatment related to the changes of Rubisco activase? BioMetals 2008; 212: 211-17.

176. Su MY, Liu C, Qu CX, Zheng L, Chen L, Huang H, et al. Nano-anatase relieves the inhibition of electron transport caused by linolenic acid in chloroplasts of spinach. Biol Trace Elem Res 2008; 122: 73-81.

177. Lei Z, Mingyu S, Xiao W, Chao L, Chunxiang Q, Liang C, et al. Antioxidant Stress is Promoted by Nano-anatase in Spinach Chloroplasts Under UV-B Radiation. Biol Trace Elem Res 2008; 121: 69-79. 
178. Lu CM, Zhang CY, Wen JQ, Wu GR. (in Chinese). Soybean Sci 2002; 21: 16871.

179. Matsunaga T, Tomoda R, Nakajima T, Wake H. Photoelectrochemical sterilization of microbial cells by semiconductor powders. FEMS Microbiol Lett 1985; 29: 211-4.

180. Ibáńez JA, Litter MI, Pizarro RA. Photocatalytic bactericidal effect of TiO2 on Enterobacter cloacae: Comparative study with other Gram (-) bacteria. J Photochem Photobiol, A 2003; 157: 81-5.

181. Jang HD, Kim S-K, Kim S-J. Effect of particle size and phase composition of titanium dioxide nanoparticles on the photocatalytic properties. J Nanopart Res 2001; 3: 141-7.

182. Shang C, Cheung LM, Ho C-M, Zeng M. Repression of photoreactivation and dark repair of coliform bacteria by TiO2-modified UV-C disinfection. App Catal B 2009; 89: 536-42.

183. Khan U, Benabderrazik N, Bourdelais AJ, Baden DG, Rein K, Gardinali PR, et al. UV and solar TiO2 photocatalysis of brevetoxins (PbTxs). Toxicon 2010; 55: 1008-16.

184. Prijic S, Sersa G. Magnetic nanoparticles as targeted delivery systems in oncology. Radiol Oncol 2011; 45: 1-16.

185. Lagopati N, Kitsiou PV, Kontos Al, Venieratos P, Kotsopoulou E, Kontos AG, et al. Photo-induced treatment of breast epithelial cancer cells using nanostructured titanium dioxide solution. J Photochem Photobiol, A 2010; 214: $215-23$

186. Stefanou E, Eyangelou A, Falaras P. Effects of UV-irradiated titania nanoparticles on cell proliferation, cancer metastasis and promotion. Catal Today 2010; 151: 58-63.

187. Cai R, Kubota Y, Shuin T, Sakai H, Hashimoto K, Fujishima A. Induction of cytotoxicity by photoexcited TiO2 particles. Cancer Res 1992; 52: 2346-8.

188. Fujishima A, Hashimoto K, Watanabe T. TiO2 Photocatalysis: Fundamentals and Applications. Tokyo: BKC, Inc; 1999.

189. Fujishima A, Call RX, Otsuki J, Hashimoto K, Iron K, Yamashita T, et al. Biochemical application of photoelectrochemistry: photokilling of malignant cells with TiO2 powder. Electrochim Acta 1993; 38: 153-7.

190. Kalbacova M, Macak MJ, Schmidt-Stein F, Mierke CT, Schmuki P. Phys. Status Solidi (RRL). 2008; 2: 194-8.

191. Kubota Y, Shuin T, Kawasaki C, Hosaka M, Kitamura H, Cai R et al. Photokilling of T-24 Human Bladder-Cancer Cells with Titanium-Dioxide. $B r$ J Cancer 1994; 70: 1107-11.

192. Thevenot P, Cho J, Wavhal D, Timmons RB, Tang L. Surface chemistry influences cancer killing effect of TiO2 nanoparticles. Nanomedicine 2008; 43: 226-36.

193. Song M, Zhang RY, Dai YY, Gao F, Chi HM, Lv G, et al. The in vitro inhibition of multidrug resistance by combined nanoparticulate titanium dioxide and UV irradition. Biomaterials 2006; 27: 4230-38.

194. Schmidt-Stein F, Hahn R, Gnichwitz JF, Song YY, Shrestha NK, Hirsch A, et al. $X$-ray induced photocatalysis on TiO2 and TiO2 nanotubes: Degradation of organics and drug release. Electrochem Commun 2009; 1111: 2077-80.

195. Matsui K, Segawa M, Tanaka T, Kondo A, Ogino C. Antibody-immobilized TiO2 nanoparticles for cancer therapy. J Biosci Bioeng 2009; 108: S36-S37.

196. Xu J, Sun Y, Huang JJ, Chen CM, Liu GY, Jiang Y et al. Photokilling cancer cells using highly cell-specific antibody-TiO2 bioconjugates and electroporation. Bioelectrochem 2007; 712: 217-22.

197. Lai T-Y, Lee W-C. Killing of cancer cell line by photoexcitation of folic acidmodified titanium dioxide nanoparticles.J Photochem Photobiol, A 2009; 204: 148-53.

198. Lomer MCE, Hutchinson C, Volkert S, Greenfield SM, Catterall A, Thompson $\mathrm{RPH}$ et al. Dietary sources of inorganic microparticles and their intake in healthy subjects and patients with Crohn's disease. Brit J Nutr 2004; 92: 947-55. 